Prepared for the Federal Emergency Management Agency, Region 1

\title{
Scoping of Flood Hazard Mapping Needs for Merrimack County, New Hampshire
}

Open-File Report 2006-1127 


\section{Scoping of Flood Hazard Mapping Needs for Merrimack County, New Hampshire}

By Robert H. Flynn

In cooperation with the

Federal Emergency Management Agency, Region 1

Open-File Report 2006-1127

U.S. Department of the Interior

U.S. Geological Survey 


\title{
U.S. Department of the Interior P. Lynn Scarlett, Acting Secretary
}

\author{
U.S. Geological Survey \\ P. Patrick Leahy, Acting Director
}

U.S. Geological Survey, Reston, Virginia: 2006

For sale by U.S. Geological Survey, Information Services
Box 25286, Denver Federal Center
Denver, CO 80225
For more information about the USGS and its products:
Telephone: 1-888-ASK-USGS
World Wide Web: http://www.usgs.gov/
Any use of trade, product, or firm names in this publication is for descriptive purposes only and does not imply
endorsement by the U.S. Government.
Although this report is in the public domain, permission must be secured from the individual copyright owners to
reproduce any copyrighted materials contained within this report. 


\section{Contents}

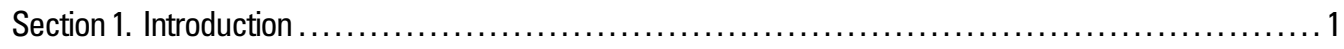

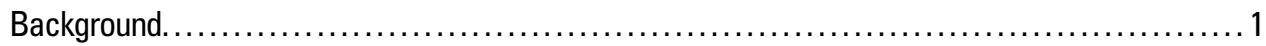

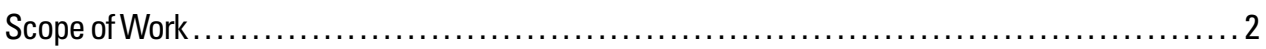

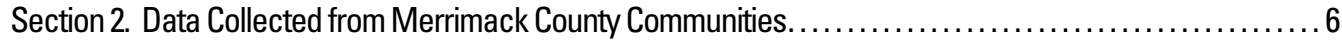

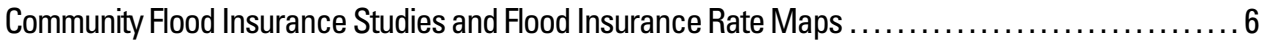

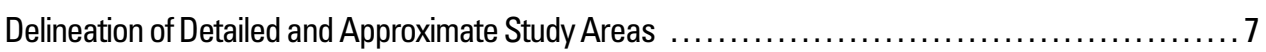

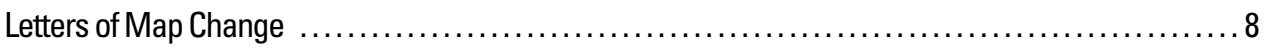

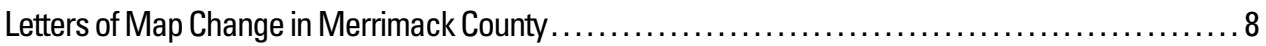

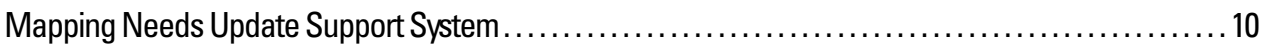

Mapping Needs in Merrimack County, New Hampshire ............................... 10

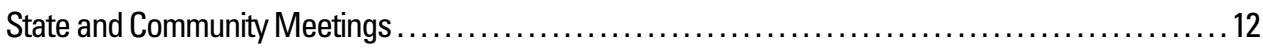

Meeting with New Hampshire Office of Emergency Management (NHOEM) and

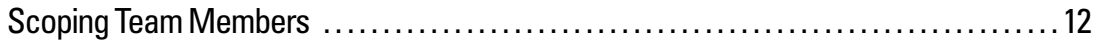

Merrimack County Community Meetings ..................................... 13

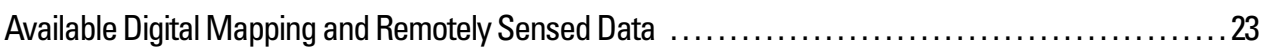

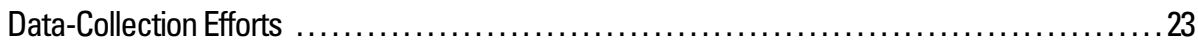

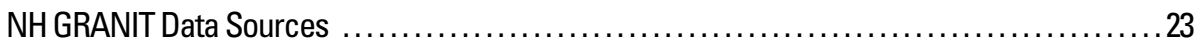

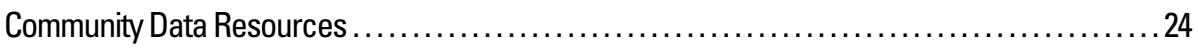

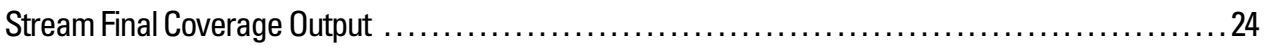

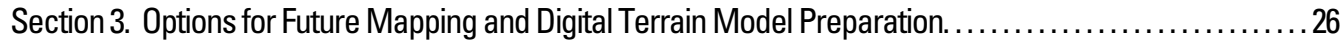

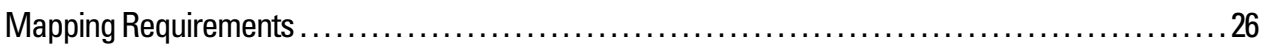

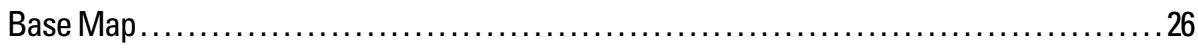

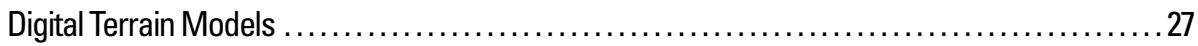

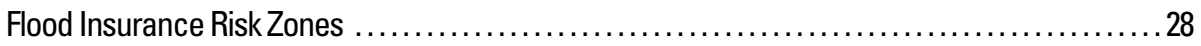

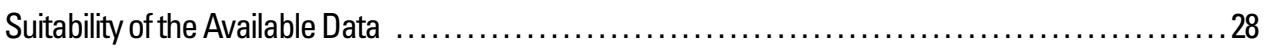

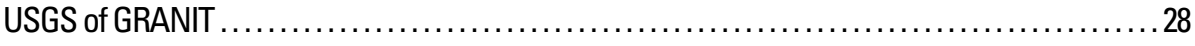

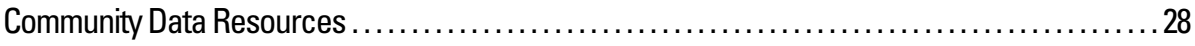

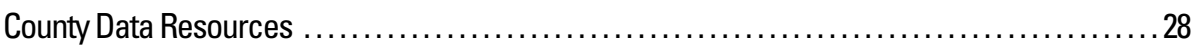

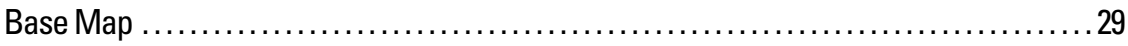

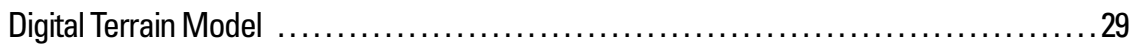

Flood Insurance Risk Zones ............................................ 29

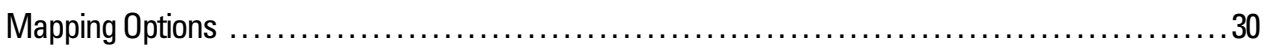

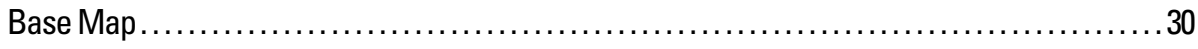

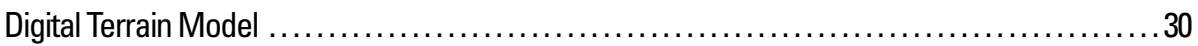

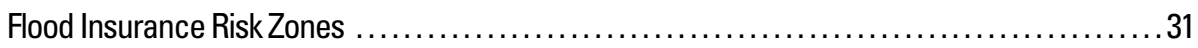

Section 4. Hydrologic and Hydraulic Restudy Needs and Prioritization ........................... 31

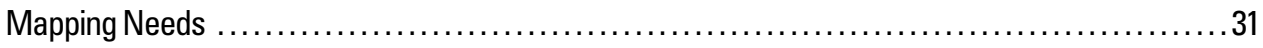

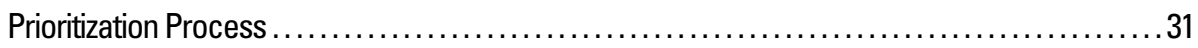

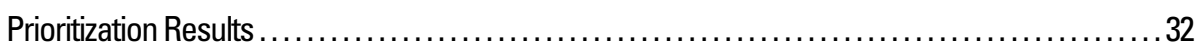

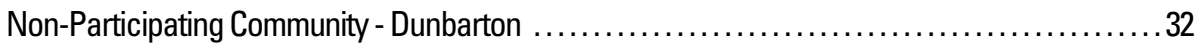

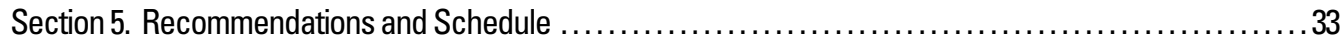

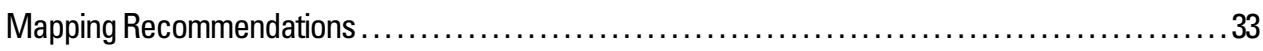

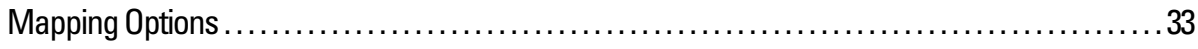




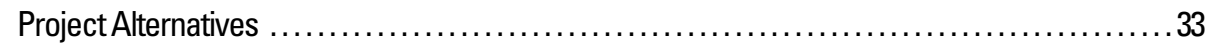

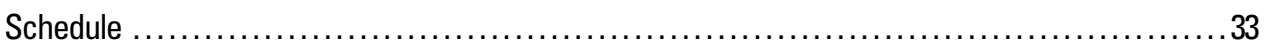

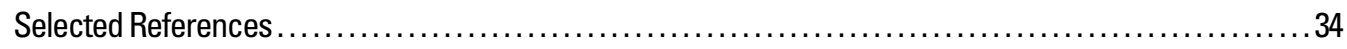

Appendixes:

Appendix A. Summary of Letters of Map Change (LOMC) Data in Merrimack County ...................35

Appendix B. Mapping Needs Update Support System (MNUSS) Needs Assessment Reports .............. 37

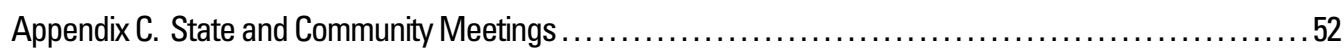

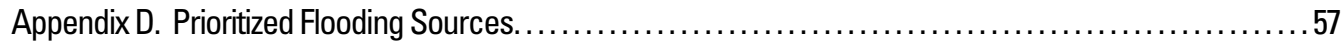

\section{Figures}

1. Merrimack County, New Hampshire, location map ...................................... 4

2. Merrimack County, New Hampshire, hydrography and FEMA Digital Flood Insurance Rate Map

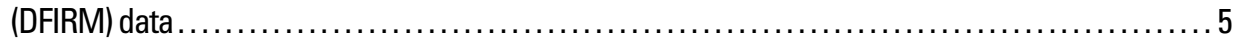

3. Letter of Map Change (LOMC) and community location map in Merrimack County, New Hampshire.....9

4. Merrimack County, New Hampshire, stream final coverage ............................... 25

\section{Tables}

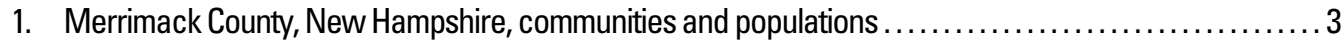

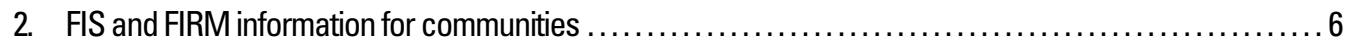

3. Summary of specific mapping needs in Merrimack County, New Hampshire ....................... 11

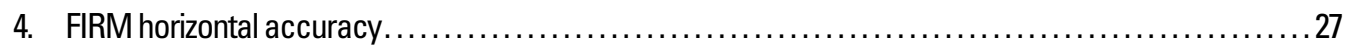

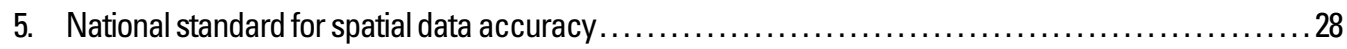

6. Currently available high resolution orthophotography for Merrimack County....................29

7. Estimate of costs to obtain Digital Terrain Model data (2-ft contours)............................ 30

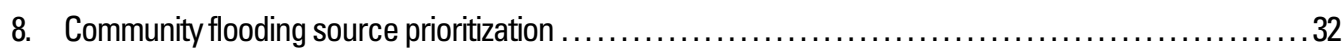


CONVERSION FACTORS AND ABBREVIATIONS

\begin{tabular}{|c|c|c|}
\hline Multiply & By & To obtain \\
\hline \multicolumn{3}{|c|}{ Length } \\
\hline inch (in.) & 25.4 & millimeter $(\mathrm{mm})$ \\
\hline foot $(\mathrm{ft})$ & 0.3048 & meter $(\mathrm{m})$ \\
\hline mile (mi) & 1.609 & kilometer $(\mathrm{km})$ \\
\hline \multicolumn{3}{|c|}{ Area } \\
\hline square foot $\left(\mathrm{ft}^{2}\right)$ & 0.09290 & square meter $\left(\mathrm{m}^{2}\right)$ \\
\hline square inch $\left(\mathrm{in}^{2}\right)$ & 6.452 & square centimeter $\left(\mathrm{cm}^{2}\right)$ \\
\hline square mile $\left(\mathrm{mi}^{2}\right)$ & 2.590 & square kilometer $\left(\mathrm{km}^{2}\right)$ \\
\hline \multicolumn{3}{|c|}{ Volume } \\
\hline cubic foot $\left(\mathrm{ft}^{3}\right)$ & 0.02832 & cubic meter $\left(\mathrm{m}^{3}\right)$ \\
\hline \multicolumn{3}{|c|}{ Slope } \\
\hline foot per mile (ft/mi) & 0.1894 & meter per kilometer $(\mathrm{m} / \mathrm{km})$ \\
\hline \multicolumn{3}{|c|}{ Velocity and Flow } \\
\hline foot per second (ft/s) & 0.3048 & meter per second $(\mathrm{m} / \mathrm{s})$ \\
\hline cubic foot per second $\left(\mathrm{ft}^{3} / \mathrm{s}\right)$ & 0.02832 & cubic meter per second $\left(\mathrm{m}^{3} / \mathrm{s}\right)$ \\
\hline
\end{tabular}

Horizontal coordinate information is referenced to the insert datum name (and abbreviation) here for instance, “North

American Datum of 1983 (NAD 83)."

\section{OTHER ABBREVIATIONS USED IN REPORT}

$\begin{array}{ll}\text { APFO } & \text { Aerial Photography Field Office } \\ \text { BFE } & \text { Base Flood Elevation } \\ \text { CAC } & \text { Community Assistance Contact } \\ \text { CAV } & \text { Community Assistance Visit } \\ \text { cfs } & \text { cubic feet per second } \\ \text { CID } & \text { Community Identification } \\ \text { CIS } & \text { Community Information System } \\ \text { COTR } & \text { Contracting Officer's Technical Representative } \\ \text { CTP } & \text { Cooperating Technical Partner } \\ \text { DEM } & \text { Digital Elevation Model } \\ \text { DFIRM } & \text { Digital Flood Insurance Rate Map } \\ \text { DOQ } & \text { Digital Orthophoto Quadrangle } \\ \text { DOQQ } & \text { Digital Ortho Quarter Quadrangle } \\ \text { DTM } & \text { Digital Terrain Model } \\ \text { FBFM } & \text { Flood Boundary and Floodway Map } \\ \text { FEMA } & \text { Federal Emergency Management Agency } \\ \text { FHBM } & \text { Flood Hazard Boundary Map }\end{array}$




\begin{tabular}{|c|c|}
\hline FIRM & Flood Insurance Rate Map \\
\hline FIS & Flood Insurance Study \\
\hline GIS & Geographic Information System \\
\hline GRANIT & Geographically Referenced ANalysis and Information Transfer system \\
\hline GSP & Ground Sample Distance \\
\hline $\mathrm{H} \& \mathrm{H}$ & Hydrologic and Hydraulic \\
\hline LiDAR & Light Detection and Ranging \\
\hline LOMA & Letter of Map Amendment \\
\hline LOMC & Letters of Map Change \\
\hline LOMR & Letter of Map Revision \\
\hline LOMR-F & Letter of Map Revision based on Fill \\
\hline MNA & Mapping Needs Assessment \\
\hline MNUSS & Mapping Needs Update Support System \\
\hline MrSID & Multi-resolution Seamless Image Database \\
\hline NAIP & National Agriculture Imagery Program \\
\hline NDOP & National Digital Ortho Program \\
\hline NED & National Elevation Dataset \\
\hline NFIP & National Flood Insurance Program \\
\hline NHD & National Hydrography Dataset \\
\hline NHDOT & New Hampshire Department of Transportation \\
\hline NHOEM & New Hampshire Office of Emergency Management \\
\hline NHOEP & New Hampshire Office of Energy and Planning \\
\hline NSSDA & National Standard for Spatial Data Accuracy \\
\hline RMC & Regional Management Center \\
\hline SFHA & Special Flood Hazard Area \\
\hline TIN & Triangulated Irregular Network \\
\hline UNH & University of New Hampshire \\
\hline USACE & United States Army Corps of Engineers \\
\hline USDA & United States Department of Agriculture \\
\hline USEPA & United States Environmental Protection Agency \\
\hline USGS & United States Geological Survey \\
\hline UTM & Universal Transverse Mercator \\
\hline WISE & Watershed Information System \\
\hline
\end{tabular}




\title{
Scoping of Flood Hazard Mapping Needs for Merrimack County, New Hampshire
}

\author{
By Robert H. Flynn
}

\section{Section 1. Introduction}

This report was prepared by the U.S. Geological Survey (USGS) New Hampshire/VermontWater Science Center for scoping of flood-hazard mapping needs for Merrimack County, New Hampshire, under Federal Emergency Management Agency (FEMA) Inter-Agency agreement Number HSFE01-05X-0018. This section of the report explains the objective of the task and the purpose of the reports.

\section{Background}

FEMA is embarking on a map modernization program nationwide to:

1. Gather and develop updated data for all flood prone areas in support of floodplain management.

2. Provide maps and data in a digital format for the improvement in the efficiency and precision of the mapping program.

3. Integrate FEMA's community and state partners into the mapping process.

One of the priorities for FEMA, Region 1, is to develop updated Digital Flood Insurance Rate Maps (DFIRMs) and Flood Insurance Studies (FIS) for Merrimack County, New Hampshire. The information provided in this report will be used to develop the scope for the first phase of a multiyear project that will ultimately result in the production of new DFIRMs and FIS for the communities and flooding sources in Merrimack County.

The average age of the FEMA floodplain maps in Merrimack County, New Hampshire is 18.5 years. Most of these studies were computed in the late 1970s to the mid 1980s. However, in the ensuing 2030 years, development has occurred in many of the watersheds, and the rivers and streams and their floodplains have changed as a result. In addition, as development has occurred, peak flooding has increased downstream of the development from increased flows across impervious surfaces. Therefore, many of the older studies may not depict current conditions nor accurately estimate risk in terms of flood heights.

Merrimack County gained 9,317 residents between 2000 and 2004. This represents a growth of 6.8 percent compared to 5.2 percent for the state as a whole. Merrimack County ranks third (from highest to lowest) out of New Hampshire's 10 counties in terms of rate of population increase. Since 1990, Merrimack County has gained 25,537 residents (University of New Hampshire, 2005). 


\section{Scope of Work}

The following is the scope of work as defined in the FEMA/USGS Statement of Work:

Task 1: Collect data from a variety of sources including community surveys, other Federal and State Agencies, National Flood Insurance Program (NFIP) State Coordinators, Community Assistance Visits (CAVs) and FEMA archives. Lists of mapping needs will be obtained from the Mapping Needs Update Support System (MNUSS) database, community surveys, and CAVs, if available. FEMA archives will be inventoried for effective Flood Insurance Rate Maps (FIRM) panels, FIS reports, and other flood hazard data or existing study data. Best available base map information, topographic data, flood hazard data, and hydrologic and hydraulic $(\mathrm{H} \& \mathrm{H})$ data will be identified and obtained. FEMA Letters of Map Change (LOMC) areas will also be identified.

Task 2: Contact communities in Merrimack County to notify them that FEMA and the State have selected them for a map update, and that a project scope will be developed with their input. Topics to be reviewed with the communities include (1) Purpose of the Flood Map Project (for example, the update needs that have prompted the map update); (2) The community's mapping needs; (3) The community's available mapping, hydrologic, hydraulic, and flooding information; (4) Target schedule for completing the project; and (5) The community's engineering, planning, and geographic information system (GIS) capabilities. When requested by the community, or when needed to obtain information on mapping needs and available information, the USGS will schedule meetings with individual communities.

Based on the collected information from Task 1 and community contacts/meetings in Task 2, the USGS will develop a Draft Project Scope for the identified mapping needs of the communities in Merrimack County. The following items will be addressed in the Draft Project Scope: review of available information; determine if and how the currently effective FIS data can be used in new project; identify other data needed to complete the Project and its source; and the DFIRM format. The Draft Project Scope will establish priority levels for flooding sources to be analyzed and mapped, and estimate schedules for completion of the components of flood mapping.

The USGS is to supply the FEMA Contracting Officer's Technical Representative (COTR) with a report summarizing the following:

1. Available data and collected information on mapping needs.

2. Documentation of meetings and contacts.

3. Suitability of existing data and options for future mapping.

4. Restudy needs and priorities.

5. Recommended project scope and influences on cost.

This report provides a summary of data-collection efforts conducted for this task, as well as information on available mapping/remote sensing data. The report includes recommendations for providing needed mapping/remote sensing data to accomplish the ultimate goal of producing new DFIRMs. It also provides options for accomplishing this goal within the context of FEMA's Cooperating Technical Partner (CTP) Program. The report begins the process of establishing restudy priorities in Merrimack County.

The communities of Merrimack County and their populations are listed in table 1, and the location of Merrimack County in New Hampshire is shown in figure 1. The Merrimack County Hydrography and FEMA DFIRM Data, county communities, rivers and streams and flood zones are shown in figure 2. 
Table 1. Merrimack County, New Hampshire, communities and populations.

\begin{tabular}{|c|c|c|c|}
\hline County/Town & $\begin{array}{c}\text { Year } 2000 \\
\text { population }\end{array}$ & $\begin{array}{l}\text { Land area } \\
\text { (square mile) }\end{array}$ & $\begin{array}{l}\text { Population per } \\
\text { square mile }\end{array}$ \\
\hline Merrimack County & 136,225 & 954.7 & 142.7 \\
\hline Allenstown & 4,843 & 20.6 & 235.1 \\
\hline Andover & 2,109 & 41.0 & 51.4 \\
\hline Boscawen & 3,672 & 25.4 & 144.6 \\
\hline Bow & 7,138 & 28.5 & 250.5 \\
\hline Bradford & 1,454 & 35.9 & 40.5 \\
\hline Canterbury & 1,979 & 44.8 & 44.2 \\
\hline Chichester & 2,236 & 21.3 & 105.0 \\
\hline Concord & 40,687 & 67.2 & 605.5 \\
\hline Danbury & 1,071 & 38.0 & 28.2 \\
\hline Dunbarton & 2,226 & 31.3 & 71.1 \\
\hline Epsom & 4,021 & 34.6 & 116.2 \\
\hline Franklin & 8,405 & 29.2 & 287.8 \\
\hline Henniker & 4,433 & 44.8 & 99.0 \\
\hline Hill & 992 & 26.7 & 37.2 \\
\hline Hooksett & 11,721 & 37.1 & 315.9 \\
\hline Hopkinton & 5,399 & 45.1 & 119.7 \\
\hline Loudon & 4,481 & 46.7 & 96.0 \\
\hline New London & 4,116 & 25.4 & 162.0 \\
\hline Newbury & 1,702 & 38.1 & 44.7 \\
\hline Northfield & 4,548 & 28.9 & 157.4 \\
\hline Pembroke & 6,897 & 22.8 & 302.5 \\
\hline Pittsfield & 3,931 & 24.3 & 161.8 \\
\hline Salisbury & 1,137 & 39.8 & 28.6 \\
\hline Sutton & 1,544 & 43.3 & 35.7 \\
\hline Warner & 2,760 & 55.5 & 49.7 \\
\hline Webster & 1,579 & 28.8 & 54.8 \\
\hline Wilmot & 1,144 & 29.6 & 38.6 \\
\hline
\end{tabular}




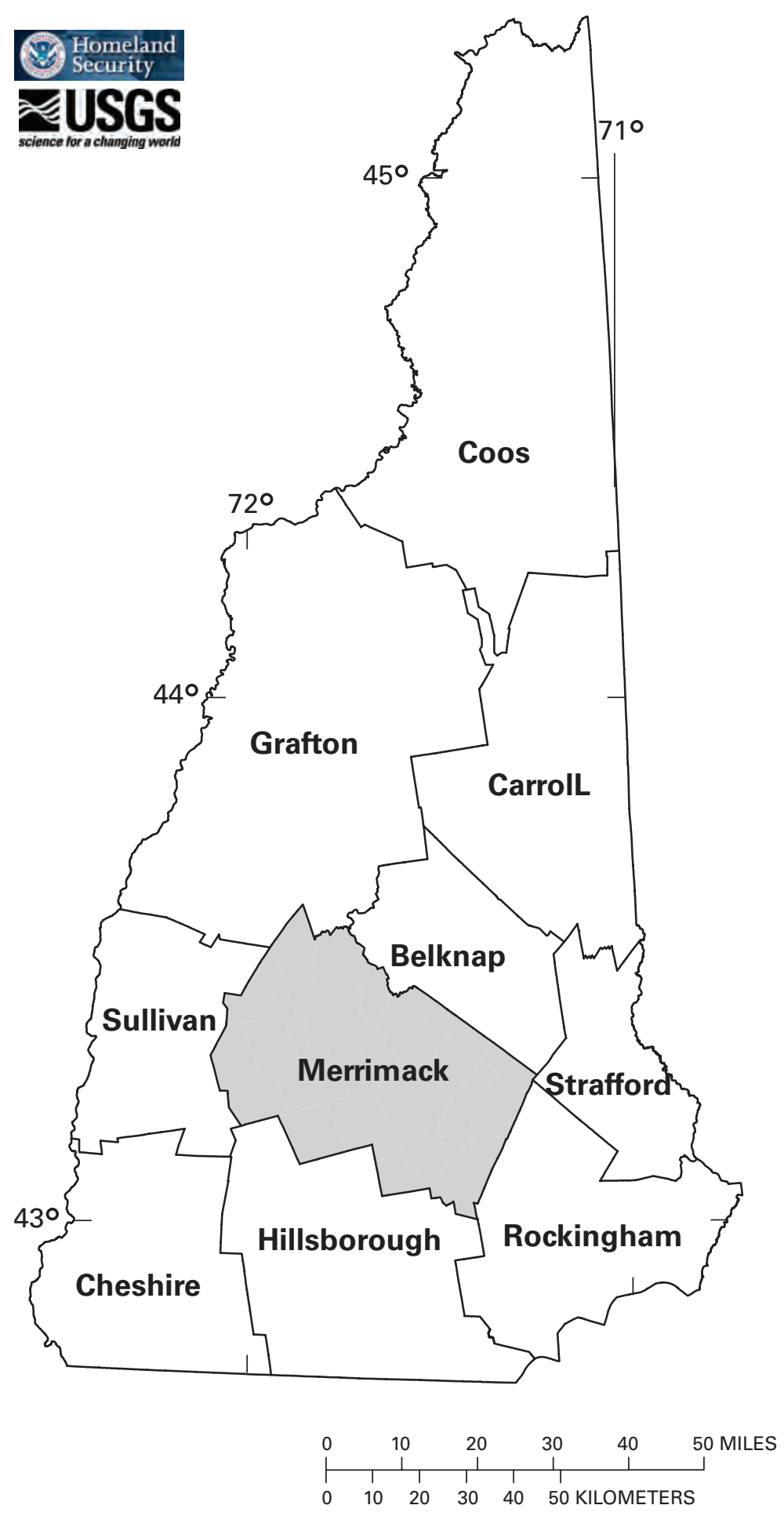

Figure 1. Merrimack County, New Hampshire, location map. 


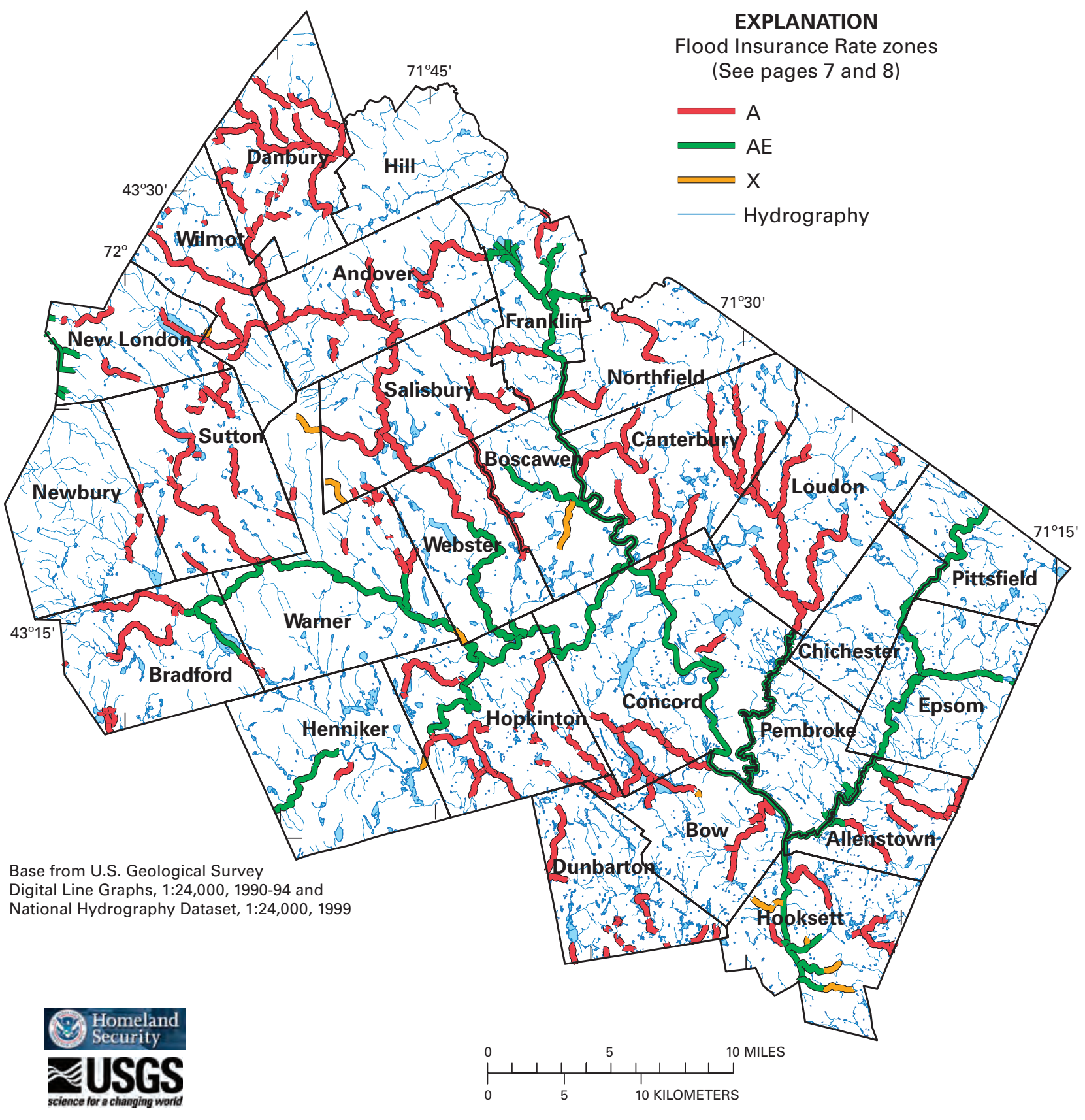

Figure 2. Merrimack County, New Hampshire, hydrography and FEMA Digital Flood Insurance Rate Map (DFIRM) data. 


\section{Section 2. Data Collected from Merrimack County Communities}

This section provides a summary of the data-collection efforts for communities in Merrimack County relating to the most recent community FISs and FIRMs; Letter of Map Amendments (LOMAs) and Letter of Map Revisions (LOMRs); information from the MNUSS database; and state and community meetings, and information on the location of existing remote-sensing data.

The flood-hazard information obtained in the data-collection efforts are summarized in figure 2 , and include:

- State, county, and community boundaries.

- Water features.

- Limits of existing detailed and approximate study within Merrimack County.

These maps can be continually updated in the future as new information becomes available.

\section{Community Flood Insurance Studies and Flood Insurance Rate Maps}

A summary of FIS and FIRM dates for the communities located in Merrimack County are listed in table 2 .

Table 2. FIS and FIRM information for communities.

[FIS, Flood Insurance Studies; FIRM, Flood Insurance Rate Map; FHBM, Flood Hazard Boundary Map; --, no data]

\begin{tabular}{lccc}
\hline \multicolumn{1}{c}{ Community } & Date of entry & FIRM/FHBM date & FIS date \\
\hline Allenstown & $4 / 2 / 1979$ & $4 / 2 / 1979$ & $10 / 1978$ \\
Andover & $4 / 2 / 1986$ & $4 / 2 / 1986$ & -- \\
Boscawen & $7 / 16 / 1979$ & $7 / 16 / 1979$ & $1 / 1979$ \\
Bow & $4 / 16 / 1979$ & $11 / 20 / 2000$ & $11 / 20 / 2000$ \\
Bradford & $4 / 15 / 1992$ & $4 / 15 / 1992$ & $4 / 15 / 1992$ \\
& & & \\
Canterbury & $5 / 15 / 1979$ & $5 / 15 / 1979$ & $11 / 1978$ \\
Chichester & $5 / 14 / 2004$ & $9 / 1 / 1978$ & $3 / 1978$ \\
Concord, City of & $3 / 4 / 1980$ & $8 / 23 / 1999$ & $8 / 23 / 1999$ \\
Danbury & $1 / 1 / 2003$ & $1 / 1 / 2003$ & -- \\
Dunbarton & $3 / 28 / 2001$ & $(\mathrm{NSFHA})$ & -- \\
& & & \\
Epsom & $7 / 3 / 1978$ & $7 / 3 / 1978$ & $1 / 1978$ \\
Franklin, City of & $9 / 28 / 1979$ & $9 / 28 / 1979$ & $3 / 1979$ \\
Henniker & $3 / 14 / 1979$ & $5 / 1 / 1978$ & $11 / 1977$ \\
Hill & $4 / 2 / 1986$ & $2 / 26 / 2002$ & -- \\
Hooksett & $4 / 2 / 1979$ & $3 / 12 / 1982$ & $3 / 1982$
\end{tabular}


Table 2. FIS and FIRM information for communities.-Continued

[FIS, Flood Insurance Studies; FIRM, Flood Insurance Rate Map; FHBM, Flood Hazard Boundary Map; --, no data]

\begin{tabular}{llcc}
\hline \multicolumn{1}{c}{ Community } & Date of entry & FIRM/FHBM date & FIS date \\
\hline Hopkinton & $5 / 17 / 1988$ & $5 / 17 / 1988$ & $5 / 17 / 1988$ \\
Loudon & $8 / 1 / 2004$ & $8 / 1 / 2004$ & -- \\
New London & $7 / 16 / 1991$ & $7 / 16 / 1991$ & $7 / 16 / 1991$ \\
Newbury & $4 / 2 / 1986$ & $4 / 2 / 1986$ & -- \\
Northfield & $6 / 15 / 1979$ & $6 / 15 / 1979$ & $12 / 1978$ \\
& & & \\
Pembroke & $4 / 2 / 1979$ & $4 / 2 / 1979$ & $10 / 1978$ \\
Pittsfield & $7 / 3 / 1978$ & $7 / 3 / 1978$ & $1 / 1978$ \\
Salisbury & $4 / 15 / 1986$ & $4 / 15 / 1986$ & -- \\
Sutton & $5 / 17 / 1977$ & $5 / 17 / 1977$ & -- \\
Warner & $6 / 4 / 1987$ & $6 / 4 / 1987$ & $6 / 4 / 1987$ \\
& & & \\
Webster & $4 / 15 / 1986$ & $6 / 2 / 1993$ & $6 / 2 / 1993$ \\
Wilmot & $4 / 1 / 1986$ & $4 / 1 / 1986$ & -- \\
\hline
\end{tabular}

${ }^{1}$ NSFHA, No Special Flood Hazard Area, All Zone C.

The effective map dates range from 1977 in the Town of Sutton to 2004 in the Town of Loudon. Fifty percent of the FIRMs were produced prior to 1986 and are 20 years old or older. The oldest FIRM is 28 years old, the most recent is 1 year old, and the average is 18.5 years old. Most (over

70 percent) of the FIS analyses were performed between 1977 and 1988 and have not been updated.

\section{Delineation of Detailed and Approximate Study Areas}

Digital Q3 Flood Data have not been developed for Merrimack County to determine the areas of detailed study (zone AE) and areas of approximate study (zone A) within the communities. FEMA digital Q3 flood data is the electronically scanned currently effective map panels of an existing paper FIRM. Digital FIRM Data were created and provided by the University of New Hampshire Geographically Referenced ANalysis and Information Transfer system (UNH GRANIT) (Jenn Merriam, written commun., October 14, 2005) for this report. These data had not been quality checked by FEMA's contractors as of the date received. GRANIT, a collaborative effort between the University of New Hampshire and the New Hampshire Office of Energy and Planning (NHOEP), is a cooperative project to create, maintain, and make available a statewide geographic data base serving the information needs of state, regional, and local decisionmakers. Definitions of flood insurance rate zones A and AE are provided below:

- Zone AE: Zone AE is the flood insurance rate zone that corresponds to the 100 -year floodplains that are determined in the FIS by detailed methods. In most instances, whole-foot base flood elevations (BFEs) derived from the detailed hydraulic analyses are shown at selected intervals within this zone.

- Zone A: Zone A is the flood insurance rate zone that corresponds to the 100-year floodplains that are determined in the FIS by approximate methods. Because detailed hydraulic analyses are not performed for these areas, no BFEs or depths are shown within this zone. 
- Zone X: The flood insurance rate zone that corresponds to areas outside of the 500-year floodplain, areas within the 500-year floodplain, and to areas of the 100-year floodplain where average depths are less than 1 foot, areas of the 100-year flooding where the contributing drainage area is less than 1 square mile, and areas protected from the 100-year flood by levees. No BFEs or depths are shown in this zone.

\section{Letters of Map Change}

A LOMC is a letter issued by FEMA in response to a request to revise or amend an effective NFIP map to remove a property or reflect changed flooding conditions on the effective map. LOMCs may include LOMAs and LOMRs, as defined below:

- LOMAs: A LOMA is an official amendment, by letter, to an effective NFIP map. A LOMA establishes a property's location in relation to the Special Flood Hazard Area (SFHA). There is no appeal period for LOMAs, and the letter becomes effective the date that it is sent.

- LOMRs: A LOMR is an official revision, by letter, to an effective NFIP map. A LOMR may change flood insurance risk zones, floodplain and(or) floodway boundary delineations, planimetric features, and(or) BFEs. The effective date of a LOMR depends on the type of change requested. For example, some LOMR's are effective on the date that the letter is issued and others become effective following an appeal period (typically 30 to 90 days or 6 months).

- LOMR-F: A Letter of Map Revision based on Fill (LOMR-F) may be filed as a special case of the LOMR. A LOMR-F provides FEMA's determination concerning whether a structure or parcel has been elevated on fill above the BFE and excluded from the SFHA. A LOMR-F is an official revision, by letter, to an effective NFIP map. The letter becomes effective on the date that it is sent.

In addition to the categories above, conditional LOMAs, LOMRs, and LOMR-Fs may be issued by FEMA to comment on a proposed project. The letter does not revise an effective NFIP map, but indicates whether the project, if built as proposed, would be recognized by FEMA.

\section{Letters of Map Change in Merrimack County}

LOMCs were collected for each of the communities.

A summary of the LOMCs obtained from FEMA (http://msc.fema.gov) and the NHOEM is provided in appendix A. The summary table in appendix A includes the LOMC case number, effective date, flooding source, location, area/structure removed from SFHA, and new flood zone. The location of each LOMC is shown in figure 3. 


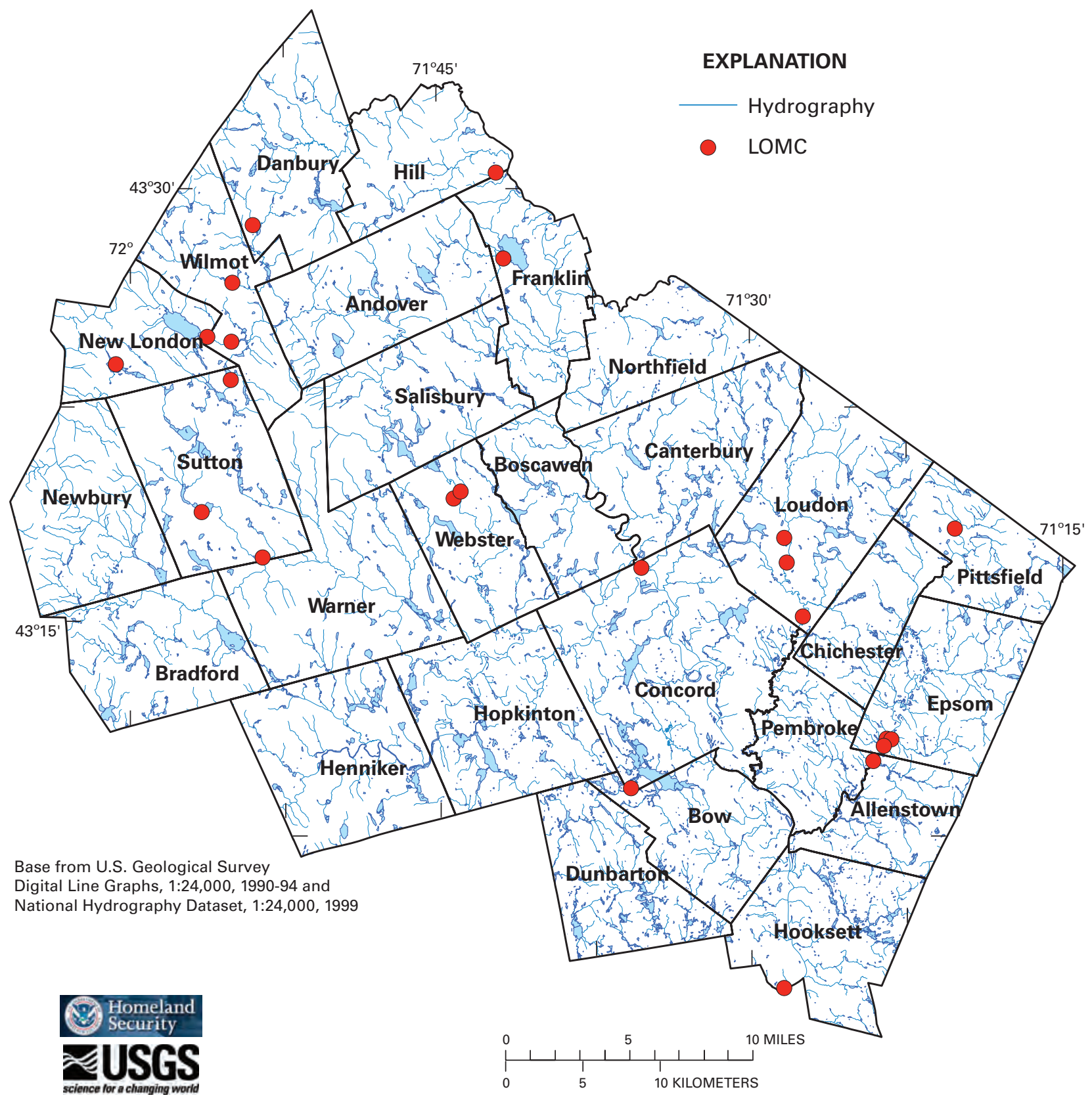

Figure 3. Letter of Map Change (LOMC) and community location map in Merrimack County, New Hampshire. 


\section{Mapping Needs Update Support System}

In accordance with section 575 of the National Flood Insurance Reform Act of 1994, FEMA assesses "...the need to revise and update all floodplain areas and flood-risk zones identified, delineated, or established based on analysis of all natural hazards affecting flood risks." FEMA initiated the Mapping Needs Assessment (MNA) process, which identifies and prioritizes flood-hazard mapping needs for communities nationwide. As part of this effort, FEMA developed the MNUSS, which is an interactive, web-based software application that maintains an inventory of needs for future map updates. In particular, MNUSS stores information on the following two types of update needs:

- Map Maintenance Needs: Includes changes to base map information, such as the addition of new roads, changes to corporate limits, and incorporation of LOMCs.

- Flood Data Update Needs: Includes changes to flood-hazard areas as a result of changes in H\&H conditions, changes to BFEs, and(or) changes in the floodplain delineation.

Mapping needs may be viewed and entered into MNUSS by a variety of parties, including FEMA Headquarters and Regional offices, state NFIP coordinators, study contractors, CTPs, and other Federal agencies, such as the U.S. Army Corps of Engineers (USACE) and the USGS. All needs are reviewed and approved by the FEMA MNUSS controller prior to office entry into the system.

\section{Mapping Needs in Merrimack County, New Hampshire}

Information on mapping needs for the respective communities within Merrimack County was downloaded from MNUSS on August 17, 2005, and is included in appendix B. This information included a summary of those communities that had and had not responded to requests for information on MNUSS mapping needs, as well as a summary of the map maintenance and flood-data-update needs, as appropriate, for those communities where responses had been received. A summary of the response status for each community and the general mapping needs are listed in appendix table B-1.Information on the specific community mapping needs is provided in table 3 . 
Table 3. Summary of specific mapping needs in Merrimack County, New Hampshire.

[BFE, Base Flood Elevation]

\begin{tabular}{|c|c|c|c|}
\hline Community & $\begin{array}{l}\text { Need } \\
\text { identifier }\end{array}$ & $\begin{array}{l}\text { Study } \\
\text { category }\end{array}$ & Comments \\
\hline Andover & 10603 & Maintenance & Add streets to panels (no panels were associated with need). \\
\hline Bow & 10565 & Riverine & $\begin{array}{l}\text { Increase in BFE by between } 1 \text { and } 5 \mathrm{ft} \text { on } 5.87 \mathrm{mi} \text { stretch on the Merrimack } \\
\text { River. }\end{array}$ \\
\hline Epsom & 10570 & Riverine & $\begin{array}{l}\text { Changes to hydraulic analysis on Northwood Lake with an anticipated BFE } \\
\text { decrease of less than } 1 \text { foot over } 1.86 \mathrm{mi} \text {. }\end{array}$ \\
\hline \multirow[t]{2}{*}{ Henniker } & 10594 & Maintenance & Add streets to panel $0025 \mathrm{~B}$. \\
\hline & 10595 & Riverine & $\begin{array}{l}\text { Changes to hydrologic conditions with an anticipated BFE increase of greater } \\
\text { than } 5 \mathrm{ft} \text { along } 2 \mathrm{mi} \text { of an unnamed zone A area. }\end{array}$ \\
\hline \multirow[t]{5}{*}{ Hooksett } & 29312 & Maintenance & Add streets to panels $0005 \mathrm{C}, 0010 \mathrm{C}, 0015 \mathrm{C}$, and $0020 \mathrm{C}$. \\
\hline & 29315 & Riverine & $\begin{array}{l}\text { Changes in hydrologic and hydraulic conditions with an anticipated BFE } \\
\text { decrease of less than } 1 \text { foot over } 1.4 \text { mi of Maple Falls Brook (county boundary } \\
\text { to Dubes Pond Dam). }\end{array}$ \\
\hline & 29316 & Riverine & $\begin{array}{l}\text { Changes in hydrologic conditions with an anticipated BFE decrease of less than } \\
1 \text { foot over } 0.75 \text { mi of Dalton Brook (Benton Road to Berry Hill Road). }\end{array}$ \\
\hline & 29313 & Riverine & $\begin{array}{l}\text { Changes in hydrologic and hydraulic conditions with an anticipated BFE } \\
\text { decrease of less than } 1 \text { foot over } 1.7 \text { mi of Heads Pond. }\end{array}$ \\
\hline & 29314 & Riverine & $\begin{array}{l}\text { Changes in hydrologic and hydraulic conditions with an anticipated BFE } \\
\text { decrease of less than } 1 \text { foot over } 1.2 \text { mi of Dubes Pond. }\end{array}$ \\
\hline Hopkinton & 10631 & Maintenance & Align map panel 0009B. \\
\hline Pembroke & 10572 & Maintenance & Add streets to panel 0005A. \\
\hline Salisbury & 10632 & Maintenance & Add streets to panels (no panels were associated with need). \\
\hline
\end{tabular}

As shown in table 3, a total of 13 mapping update needs are listed in MNUSS throughout Merrimack County. These include six map maintenance needs and seven flood-data-update needs. Not all of the communities in the county responded to the FEMA request for information regarding mapping needs, so the actual number of mapping needs may be higher than what is currently reported in MNUSS. Additional information on mapping needs in the communities was established through state and community meetings, as discussed in the following sections. 


\section{State and Community Meetings}

As part of the scoping effort, the USGS conducted a series of meetings with the following State agencies and communities:

- NHOEM on August 24, 2005, to review LOMCs.

- Conference call kick-off meeting with NHOEM, FEMA, USGS, and Watershed Concepts on September 1, 2005.

The following section provides a summary of the key outcomes from each of the State and community meetings. Additional detail is given in appendix $\mathrm{C}$, which provides copies of the meeting minutes and an example community interview form.

\section{Meeting with New Hampshire Office of Emergency Management(NHOEM) and Scoping Team Members}

USGS held a kick-off meeting with a conference call on September 1, 2005, that included representatives from NHOEM, FEMA, USGS, and Watershed Concepts (RMC - Regional Management Center). The meeting was used to introduce the scoping project team and review roles and responsibilities. The meeting agenda and minutes are included in appendix $\mathrm{C}$. The following people were included in the meeting:

- Dean Savramis, representing FEMA, provided an overview of the Map Modernization Program and Scoping. He also provided a description of the countywide approach.

- Brent McCarthy (RMC) described the role of the RMC in assisting FEMA and the mapping contractors. He described the Watershed Information System (WISE) (Watershed Concepts, 2005) computer applications developed for FEMA to standardize the scoping process methodology, data collection, and storage for the map modernization program. Brent mentioned that it may be a good idea to set up a morning and evening meeting with each County in order to be able to talk to all of the representatives in each town (two meetings for each county). Brent also mentioned that Watershed Concepts could lead breakout sessions with towns during the meetings with the Counties.

- Jeff Burm (RMC) spoke about the WISE Scoping tool and various features of this tool including community contact information, available GIS data, stream data, statistical analysis, stream mile information to calculate costs for hydrology and hydraulics, LOMAs, CAVs and Community Assistance Contacts (CACs), creation of reports for each of the items.

- Fay Rubin (UNH GRANIT), Craig Johnston, Laura Hayes and Robert Flynn (USGS)—discussed available data and coverages within New Hampshire (for example, 2003 National Agriculture Imagery Program (NAIP) color Digital Orthophoto Quadrangles (DOQs)). Remote sensing, base map information, GIS data (for example, contour data, E911 data, Digital Elevation Model (DEMs), buildings layer, survey data available from the New Hampshire Department of Transportation (NHDOT). In addition, the county regional planning commissions were mentioned as possible sources of data. 


\section{Merrimack County Community Meetings}

Conference calls were conducted with representatives from all of the towns in Merrimack County. The following sections provide a brief summary of the key findings from each community interview, and in particular, identifying areas with increased development, areas with known flooding problems, and areas with changes to hydraulic structures. The applicable community contacts are also provided in each section.

The goals of these meetings were to:

- Inform the communities of the nature and the intent of the flood map update process.

- Solicit community input and discuss the flood-prone areas that communities would like to include as a part of the flood map update.

Community comments were captured on paper interview forms, FIRM panels, and on working maps of each community produced for this purpose. These comments were entered into the WISE scoping application. Notes from the working maps and FIRM panels are summarized on figure 3. For communities not represented at the meetings, information provided by NHOEM, and contained in the community business plan was relied upon.

\section{Merrimack County:}

\section{Allenstown}

The following list provides a summary of the key issues identified during the community interview (August 10, 2005, October 20, 2005, and October 21, 2005):

- No new studies needed.

Contact: Everett Stone, Building Inspector (603-485-4276); Kelly Collins, Administrative Assistant to the Board of Selectmen; and Penny Touchette, Assessing Clerk (603-485-4276)

\section{Andover}

The following list provides a summary of the key issues identified during the community interview (August 10, 2005, and October 17, 2005):

- Many road names are incorrect and roads are missing from the FIRM. E911 road data are available.

- On panels 4, 5, 8 and 9, a detailed study is needed along Sucker Brook from Highland Lake to the upstream corporate limit due to flooding and development issues. Zone A delineation is also incorrect for Sucker Brook in that the flow does not go over the railroad bed (panels 4, 5, 8 and 9) or over Hoyt Road (panel 5) and flow does not go over the road (name unknown) between Highland Lake and Maple Street. Flow does not go over the road at Route 11 or Last Street (panel 9). A town maintained dam is upstream on Maple Street (Tilton Brook Road) and a private dam is located approximately $200 \mathrm{ft}$. downstream of Maple Street.

- On panel 7, flow is not over the road west of Elbow Pond along Elbow Pond Road. This area needs to be re-delineated.

- On panel 8, an unnamed brook flowing from upstream of Maple Street (erroneously labeled as Taunton Hill Road on FIRM) to the southern end of Highland Lake needs to have a detailed study 
from approximately 1,000 ft upstream of West Shore Drive to 1,000 ft downstream of Route 11 due to regular flooding that is not delineated on the FIRM.

- On panel 8, a re-delineation of the flooding extent is needed across Flaghole Road (zone A) for an unnamed tributary (extent is thought to be too wide).

- On panel 9, there is no flow over Emery Road as shown for unnamed zone A tributary.

- On panel 10, there is no flow over Route 11 or Cilleyville Road as shown for the zone A delineated Blackwater River.

- On panel 11, there is no flow over the railroad tracks south of Route 4 and perpendicular to Bridge Road. Flooding is more extensive than delineated to the south along Bridge Road. On panel 11, flooding from Mitchell Brook (coming from Ragged Mountain State Forest) is more extensive (to the west) between Route 11 and the railroad tracks from Mitchell Brook and south of the railroad tracks from the Blackwater River. Flooding does not occur over the railroad tracks south of Ragged Mountain State Forest nor over South Short Street, U.S. Route 4 or the railroad tracks north of Horseshoe Pond.

- On panel 12, there is no flooding over the elevated bridge on Route 4 over the Blackwater River but there is to either side of the bridge. A detailed study is needed along the Blackwater River from the western to eastern corporate limits due to incorrectly delineated flood boundaries and development.

- On panel 12, detailed studies are needed along the two unnamed tributaries under Switch Road to their confluences with the Blackwater River.

Contact: Mark Stetson, Town Administrator (603-735-5332)

\section{Boscawen}

The following list provides a summary of the key issues identified during the community interview (August 11, 2005, September 16, 2005, and October 6, 2005):

- No new studies needed.

- Beaver Dam Brook is along the Town line with Webster. This brook needs a detailed study (according to Town of Webster official) from Walker Pond to Mutton Road due to two LOMAs issued on Long Street and Beaver Dam Drive.

Contact: Sherlene Fisher, Town Administrator (603-753-9188, ext. 303)

\section{Bow}

The following list provides a summary of the key issues identified during the community interview (August 11, 2005, and October 20, 2005):

- On panel 2, a detailed study is needed along Bow Bog Brook from I-93 to the Merrimack River. This area is currently zone $\mathrm{A}$ and is zoned as industrial by the town and has had a lot of development.

- On panel 2, a detailed study is needed along the tributary to Bow Bog Brook from I-93 to Bow Bog Brook. This area is currently zone A and is zoned as industrial by the town and has had a lot of development.

- Two-foot contour-interval data are available for purchase from Holden Engineering for the town. Contact: Bill Klubben, Director of Planning and Economic Development (603-225-3008) 


\section{Bradford}

The following list provides a summary of the key issues identified during the community interview (August 11, 2005):

- On panel 5, the Jones Road Bridge over Hoyt Brook will be replaced in 2007. This area is adjacent to a flood area designated as a Zone A and a detailed study is needed along Hoyt Brook for the extent of the current zone A.

- On panel 5, Lake Massaseekum is a Zone AE but there is dispute among the locals about elevation and a new detailed study is requested for this Lake.

- On panel 5, Lake Todd is a Zone AE and the dam is being repaired. No elevation change is supposed to occur to the dam but if the elevation does change, a new study would be required.

- On panel 5, the town of Warner has requested a restudy along the Warner River which joins Lake Massasecum at its southern end. A detailed study for the length of the Warner River from Lake Massasecum to the corporate limit with Warner, N.H., is needed.

Contact: Cheryl Behr, Town Administrator, (603-938-5900)

\section{Canterbury}

The following list provides a summary of the key issues identified during the community interview (August 11, 2005, August 31, 2005, September 8, 2005, September 16, 2005, and October 6, 2005):

- No new studies needed.

Contact: Jan Stout, Clerk to the Board of Selectmen (603-783-9955); Ben Bynum, Clerk to the Assessor (603-783-9955); Robert Fife, Member and former chairman of the Conservation Commission (603-7834416).

\section{Chichester}

The following list provides a summary of the key issues identified during the community interview (August 11, 2005):

- No new studies needed.

Contact: John Martell, Chichester Emergency Management Director (603-798-4208) and Bob Mann, Conservation Commission Chairman (603-798-5371)

\section{Concord}

The following list provides a summary of the key issues identified during the community interview (August 11, 2005):

- Burnham Brook: Brook does not run through city street.

- Delineation is incorrect for Contoocook and Suncook Rivers. The delineation was previously done with $10 \mathrm{ft}$ contours but $2 \mathrm{ft}$ contours are now available.

- Turkey River is a Zone A but a detailed study is now needed.

- Snow Pond and Turtle Pond are developing and need detailed studies.

Contact: Steve Henninger, Assistant City Planner (603-225-8580) 
The following list provides a summary of the key issues identified during the community interview (October 12, 2005):

- Due to development and improperly defined A zone along Ash Brook, a detailed study is needed from 1,500 ft above Currier Road (at confluence of two brooks) to Little Turkey Pond.

- Due to development along Millers Brook, a detailed study is needed along the entire length from the confluence with Turkey River to the headwaters (south of Little Pond Road).

- Due to development along Mill Brook, a detailed study is needed from its confluence with the Merrimack River to Batcher Mill Road.

- Due to development along Beaver Meadow Brook, a detailed study is needed from its headwaters at Chickory Court to its confluence with the Merrimack River.

- BFEs along "The Outlet" (east of Contoocook Park Dam on the Contoocook River) appear to be incorrect and a new hydraulic model is needed in this area. The 100-year flood elevation above Island Road (Section "F" along "The Outlet") is $354 \mathrm{ft}$ both in the Contoocook River and in "The Outlet." Below Island Road, in "The Outlet," the BFE is $348 \mathrm{ft}$, whereas above the Contoocook Park Dam, the BFE is $353 \mathrm{ft}$. The river can flow around Island Road, upstream of Contoocook Park Dam and so an elevation of $353 \mathrm{ft}$ appears to be more likely downstream of Island Pond Road in "The Outlet" rather than $348 \mathrm{ft}$. BFE elevations need to be checked along the entire reach of "The Outlet" and a new hydraulic model needs to be created for this area.

- Due to development and flood delineation issues with the previous FIRM, a detailed study is needed along Hackett Brook from Hoit Road (south of Hoit Road Marsh) to its confluence with Hayward Brook.

- Due to development and flood delineation issues with the previous FIRM, a detailed study is needed along Hayward Brook from the upstream corporate limit to Hoit Road.

- Concord city officials have retained the Merrimack River 1972 USACE flood-hazard delineation rather than using the FEMA 1998 flood hazard delineation although the 1998 study has been adopted by the city for insurance purposes. City officials would like a restudy along the Merrimack River to determine new hydrology and hydraulics. City officials would like to incorporate the impact of the 1936 and 1938 flood events with the upstream flood control measures in place. The 1998 FIS used the hydrology as determined in the 1980 FEMA FIS. The hydrology in the 1980 FIS references the discharges used in the 1972 USACE study. HEC-2 was used in the previous studies and HEC-RAS should be used for the revision according to the City of Concord, N.H. The 1980 study did not do calibration runs for the 1936 and 1938 high-water marks because of changes that have occurred in the floodplain since the flood events occurred but, the original USACE study (1972) does account for Merrimack River flow gage data (including the 1936 and 1938 floods) and discharge values were modified to reflect the effect of the five existing flood control structures. Floods of the magnitude of the 1936 and 1938 floods would be much less likely to occur today because of the flood control structures on the Merrimack River. A verification of the hydrology is necessary and a new hydraulic model needs to be built to determine flood elevations on the Merrimack River in Concord, N.H.

Contact: Douglas Woodward, City Planner (603-225-8515) and Steve Henninger, Asst. City Planner (603-225-8515)—Meeting at Concord City Hall on October 12, 2005 


\section{Danbury}

The following list provides a summary of the key issues identified during the community interview (August 11, 2005):

- No new studies needed.

Contact: Twila Cook, Chair of Selectmen (603-768-3313)

\section{Dunbarton}

The following list provides a summary of the key issues identified during the community interview (August 11, 2005):

- No new studies needed.

Contact: Ken Swazy, Planning and Building (603-774-3541, ext. 3)

Epsom

The following list provides a summary of the key issues identified during the community interview (August 11, 2005):

- No new studies needed.

Contact: Barbara Pellegri, Town Clerk (603-736-9002) and Betsy Bosiak, Planning Board Chairman (603-736-4477)

\section{Franklin}

The following list provides a summary of the key issues identified during the community interview (August 16, 2005, September 7, 2005, and October 6, 2005):

- No new studies needed but, Sucker Brook has been requested for restudy in Andover so detailed study needed from Webster Lake to corporate limit along Sucker Brook.

Contact: Richard Lewis, Planning Board (603-934-3900)

\section{Henniker}

The following list provides a summary of the key issues identified during the community interview (August 16, 2005, August 26, 2005, September 7, 2005, and October 6, 2005):

- No new studies needed.

Contact: Peter Flynn, Town Administrator (603-428-3221)

Hill

The following list provides a summary of the key issues identified during the community interview (2005):

- No new studies needed.

Contact: Linda Henry, Administrative Assistant (603-934-1094) 


\section{Hooksett}

The following list provides a summary of the key issues identified during the community interview (August 16, 2005, September 6, 2005, and October 7, 2005):

- On panel 5, the 500-year flood is shown as delineated across the former Bayside Airport runway; however, it is believed that flooding does not occur here and the delineation is incorrect.

- On panels 5 and 10, Heads Pond dam (privately owned by Manchester Sand and Gravel) is to be rebuilt to restore water level to historic levels. Development (Carriage Hill Subdivision) is planned in 2006 around Heads Pond (500-550 homes and a golf course). This Pond is currently designated as a zone A. The dam at the outlet is to be rebuilt to its former elevation. A detailed study is needed on this pond from the dam below Daniel Webster Highway to the southern end of the pond.

- On panel 10, a detailed study is needed to establish a BFE on Dubes Pond due to development (Farrwood subdivision) along the southwest side of the pond (approximately $1.2 \mathrm{mi}$ ). This area is currently designated as a zone A.

- On panel 15, flooding over Goonan Brook is thought not to occur (BFE $=186 \mathrm{ft})$ and it is believed that the delineation is incorrect.

- On panel 20, a detailed study is needed along Dalton Brook between Benton and Berry Hill Roads (approximately $0.75 \mathrm{mi}$ ). There is currently a detailed study in this area but the extent of flooding is thought to be inaccurate (floodplain too wide).

- Two-foot contour-interval data are available for purchase from Holden Engineering for the town.

- Many new roads in Hooksett need to be included on the flood maps. E911 roads data are available.

Contact: Charles Watson, Town Planner (603-268-0279)

Hopkinton

The following list provides a summary of the key issues identified during the community interview (August 16, 2005):

- No new studies needed.

Contact: Karen Robinson, Director of Planning (603-746-4487)

Loudon

The following list provides a summary of the key issues identified during the community interview (August 16, 2005, and September 7, 2005):

- Two-foot contour-interval data are available for purchase from Holden Engineering for the town.

- On panel 3, a detailed study is needed along the Soucook River from Route 106 (near the Route 106 and Route 129 intersection) to Route 106 (east of South Village Road)

Contact: Bob Fisk, Building Inspector (603-798-5584)

\section{New London}

The following list provides a summary of the key issues identified during the community interview (August 16, 2005, September 8, 2005, and October 11, 2005): 
- On panels 10 and 15, development is occurring around the zone A designated Little Sunapee Lake, Pleasant Lake and Messer Pond and it is believed that the current zone A delineations are incorrect. A detailed study is needed to establish BFEs on these three bodies of water.

- On panel 10, it is believed that the hydrology is correct but the delineation is incorrect on Lake Sunapee.

Contact: Peter Stanley, Zoning Administrator (603-526-4821 ext. 16)

\section{Newbury}

The following list provides a summary of the key issues identified during the community interview (August 16, 2005, and October 6, 2005):

- On panels 5 and 10, a detailed study is needed along Ring Brook beginning at the John Stark Highway and Route 103, along Ring Brook at Sutton Drive to Chalk Pond Road at the eastern corporate limit (approximately $4.0 \mathrm{mi}$ ). This area is currently designated as a zone A or not designated.

- On panel 10, a detailed study is needed along Andrew Brook from the confluence with Ring Brook at Sutton Road to 2,000 ft upstream (approximately $0.4 \mathrm{mi}$ ).

- Many new roads in Newbury that need to be included on the flood maps.

Contact: Bill Weiler, Conservation Commission (603-938-2892) and Dennis Pavalicek, Town Administrator (603-763-4940, ext. 204).

\section{Northfield}

The following list provides a summary of the key issues identified during the community interview (August 19, 2005, and September 16, 2005):

- No new studies needed.

Contact: Dana Fullweiler, Code Enforcement Officer (603-848-0409)

\section{Pembroke}

The following list provides a summary of the key issues identified during the community interview (August 19, 2005, and October 12, 2005):

- New bridge on Route 3 with new abutments over Suncook River.

- Zone A incorrect at Bachelor Road on Suncook River (elevation of property is approximately $20 \mathrm{ft}$ above stream).

- Possibly an impact by the recent building of Associated Grocers Warehouse on Soucook River.

- A company called "Pembroke 600" (Dan Scott) has impacted the floodplain at Routes 6 and 103.

- Two-foot contour-interval data are available for purchase from Holden Engineering for the town.

Contact: Peter Rowell, Code Enforcement (603-485-4747, ext. 214) and Laura Scott, Town Planner (603-485-4747) 


\section{Pittsfield}

The following list provides a summary of the key issues identified during the community interview (August 19, 2005, and October 7, 2005):

- On panel 20, Whites Pond and Clarks Pond (just to the west of Whites Pond) need a detailed study due a subdivision built around these two ponds. The dam on Whites Pond is owned by the homeowners association (Winsunvale Homeowners Association) and work is being done to the dam.

- On panel 20, Gas House Brook runs through a lot of housing and a detailed study is needed from the outlet of Clarks Pond to the Suncook River.

- It is not clear as to whether the Town Hall and houses along Joy Street are within the floodplain of the Suncook River.

Contact: Cara Marston, Assessor (603-435-6773)

\section{Salisbury}

The following list provides a summary of the key issues identified during the community interview (August 23, 2005, and October 19, 2005):

- No new studies needed.

- E911 roads data are available.

Contact: Margaret Warren, Administrative Assistant (603-648-2473) and Mr. Al Tanner, Planning Board member.

Sutton

The following list provides a summary of the key issues identified during the community interview (August 19, 2005):

- Many roads are not on the map.

- Many road names are incorrect.

Contact: Jennifer Call, Secretary to the Selectmen (603-927-4416) and Paul Parker, Highway Department (603-927-4411).

The following list provides a summary of the key issues identified during the follow-up community interview (October 17, 2005):

- Many Road names are incorrect and roads are missing from Flood Hazard Boundary map (FHBM). E911 road data are available.

- On panel 3, a LOMA was issued at Cascade Brook for French Road at the Morgan Acres subdivision. Due to development in this area, a detailed study is needed along Cascade Brook from Baker Road to just above French Road.

- On panel 11, a LOMA was issued at Lane River for Dodge Hill Road. Due to development, and flood delineation issues, a detailed study is needed for the Lane River from Dodge Hill Road (just above Route 114) to its confluence with the Warner River (panels 11 and 14). 
- On panel 14, a LOMA was issued at the Warner River for Roby Road. This area is currently designated as zone A on the 1977 town of Sutton FHBMs. A detailed study was done on the Warner River in Warner and this is shown on the 1987 FIRM for Warner. Elevations as determined in the Warner Flood Insurance Study need to be transferred to the Sutton flood maps.

Contact: Jennifer Call, Secretary to the Selectmen (603-927-4416) and Paul Parker, Highway Department (603-927-4411).

Warner

The following list provides a summary of the key issues identified during the community interview (September 15, 2005, and October 17, 2005):

- Many road names are incorrect and roads are missing from the FIRM E911 road data are not available.

- The Town of Warner Emergency Management Director would like verification that flow from Lake Massasecum in Bradford, Lake Todd in Bradford and Newbury, and Blaisdell Lake in Sutton are all included in the determination of the hydrology for the Warner River.

- On panel 15, a detailed study is needed along Davis Brook from Newmarket Road to the Warner River due to development along Newmarket Road.

- On panel 15, due to flooding and development on Horne Street, a detailed study is needed along Slaughter Brook from the Harriman Chandler State Forest to the Warner River.

- On panel 20, detailed study is needed along Stevens Brook from the confluence of Stevens and French Brooks to the Warner River due to development and flooding along North Road.

- On panel 20, a restudy is needed along the Warner River from section AP to section AK due to fill being placed in the floodplain the approximate location of sections AM and AN.

- On panel 25, a detailed study is needed along an unnamed tributary from the outlet of Day Pond to the corporate limit along Route 114 due to flooding which has occurred along Route 114 near Lake Massasecum in Bradford.

- On panel 30, a detailed study is needed along Schoodac Brook from its confluence with Frazier Brook to the Warner River.

- On panel 30, a detailed study is needed along Bog Road (also known as Brook Meadow Lane) from Poverty Plains Road to Connors Mill Road due to flooding and development along Bog Road.

- On panel 30, the delineation of Tom Pond is questionable and needs top be verified with better contour data.

Contact: Edward Mical, Emergency Management Director for the Town of Warner (603-456-3350)

\section{Webster}

The following list provides a summary of the key issues identified during the community interview (August 23, 2005, and October 6, 2005):

- Beaver Dam Brook is along the Town line with Boscawen. This brook needs a detailed study (according to Town of Webster official) from Walker Pond to Mutton Road (panels 5 and 10) due to two LOMAs issued on Long Street and Beaver Dam Drive. 
- On panels 5 and 10, a detailed study is needed on Lake Winnepocket due to development (75 homes). The dam on Lake Winnepocket is privately owned.

- On panel 10, a detailed study is needed on Pillsbury Lake due to development around the lake (160 homes). This lake has a dam.

Contact: Judy Jones, selectwoman (603-648-2272)

Wilmot

The following list provides a summary of the key issues identified during the community interview (August 23, 2005, and October 12, 2005):

- The road over the Blackwater (Pleasant) River was updated from a 1-lane to a 2-lane road.

- Campground Road was made wider and has new abutments.

- On panel 11, Cannery Brook needs a detailed study from Shindagan Brook to the Tannery Pond (Stone Bridge Road).

- On panel 11, a detailed study is needed from Tannery Pond (Wilmot Flat) to the corporate limit.

- On panel 11, a detailed study is needed on Chase Pond due to development. A LOMA was issued on Quiet Cove Road.

- On panel 9, Eagle Pond needs a detailed study due to development.

- On panels 8 and 9, a detailed study is needed along Kimpton Brook from North Wilmot Road to Eagle Pond.

Contact: Ken Grossman, Conservation Committee Member (603-526-6390) and Rhonda Gauthier, Administrative Assistant (603-526-4802) 


\section{Available Digital Mapping and Remotely Sensed Data}

This section provides an inventory of the digital data available to support the production of DFIRMs for the study area. Basic information is provided on the content, lineage, and accuracy of the products.

\section{Data-Collection Efforts}

To determine the availability of digitally available data, the USGS contacted Lynn Bjorklund (New England Liaison to USGS National Mapping), Fay Rubin (GIS Manager, NH GRANIT, UNH Complex Systems Research Center), Central New Hampshire Regional Planning Commission (CNHRPC), Southern New Hampshire Regional Planning Commission (SNHRPC), Upper Valley Lake Sunapee Regional Planning Commission (UVLSRPC), and the communities themselves. The NH GRANIT has useful base mapping.

\section{NH GRANIT Data Sources}

NH GRANIT is a cooperative project to create, maintain, and make available a statewide geographic database serving the information needs of state, regional, and local decision-makers. A collaborative effort between the UNH and the NHOEP, the core GRANIT system is housed at the UNH Institute for the Study of Earth, Oceans, and Space in Durham.

NH GRANIT maintains data layers (http://www.granit.sr.unh.edu) including features such as roads, streams, and political boundaries. Some of the base map data layers maintained by NH GRANIT have been derived from USGS data and represent many of the feature types found on USGS topographic maps. More recently developed data were derived from digital orthophotos providing improved base map accuracy.

NH GRANIT is presently converting the standard, paper FIRMs and Flood Boundary and Floodway maps (FBFMs) to DFIRMs by digitizing existing flood maps from the existing paper flood maps. The DFIRMs will depict flood risk information, and include 100- and 500-year floodplain boundaries as well as areas of minimal flood risk. NH GRANIT is using USGS 1998 DOQs as the base, and they are incorporating any LOMC that are on file with FEMA.

The Q3 flood-data product is a digital representation of certain features of FEMA's FIRM product and are created by scanning the effective FIRM paper maps and digitizing selected features and lines. The digital Q3 flood data contain the following:

1. 1-percent (100-year) and 0.2-percent (500-year) annual chance floodplain boundaries (including velocity zones),

2. Flood insurance zone designations,

3. Floodway boundaries (where available),

4. Political boundaries (State, county, and community),

5. Community and map panel identification numbers,

6. FIRM panel neatlines,

7. USGS 7.5-minute (1:24,000 scale) series topographic map neatlines, and

8. Coastal Barrier Resources System areas. 


\section{Community Data Resources}

The USGS and NH GRANIT have digital base mapping data for Merrimack County that meet FEMA requirements for DFIRM production. Community data requests were limited to topographic data suitable for hydraulic modeling (for example, 4-ft contours).

Merrimack County has high resolution digital orthophotos $(1: 12,000)$. With the exception of select locations in Hooksett, Pembroke, Bow, and Loudon (Peter Holden, Holden Engineering and Surveying, Inc., oral commun., September 6, 2005), topographic data are limited to that found on USGS topographic maps with 10 or $20-\mathrm{ft}$ contour intervals. These four towns have 2 -ft contour-interval data available for purchase through Holden Engineering. The City of Concord also has 2 -ft contour-interval data available. No other community sources of digital elevation data for FEMA flood mapping were located.

\section{Stream Final Coverage Output}

The WISE Scoping Tool organizes and stores data and assists in the prioritization of the community requests for floodplain studies. As the scoping process is completed, three coverages (maps) are created: Effective, Meeting, and Stream Final.

- Effective Coverage: Q3 flood-hazard data are not available for Merrimack County. NH GRANIT has a contract with FEMA to digitize the FIRMs and they made these nearly completed DFIRMs available to the USGS for purposes of scoping. The DFIRM data for Merrimack County was received from NH GRANIT on October 15, 2005, although it had not been Quality Assurance/ Quality Control checked at that time. Users of the WISE tool should obtain an updated version of the DFIRM data when it becomes available in December of 2006. The DFIRM information was entered into the WISE scoping tool. The initial Scoping Tool database was set up using the U.S. Environmental Protection Agency (USEPA) National Hydrography Dataset (NHD) stream centerline coverage (http://nhd.usgs.gov/data.html) and digital flood boundary base mapping data provided by NH GRANIT. The NHD stream centerline coverage was used to build the Effective Coverage in the Scoping Tool. The digitized flood-hazard data were overlain onto the NHD stream centerline coverage. The Scoping Tool was used to enter each reach of the Effective Coverage one at a time by assigning the beginning and end of each reach and the current effective type of study.

- Meeting Coverage: The Effective Coverage was used to prepare the work maps for recording mapping needs requested by the communities during the Scoping Meetings. These requests were also recorded in the Meeting Coverage of the Scoping Tool.

- Stream Final Coverage: The WISE Scoping Tool was used to create a Stream Final Coverage to document and highlight community meeting results. Community mapping needs based on community input are summarized in figure 4. 


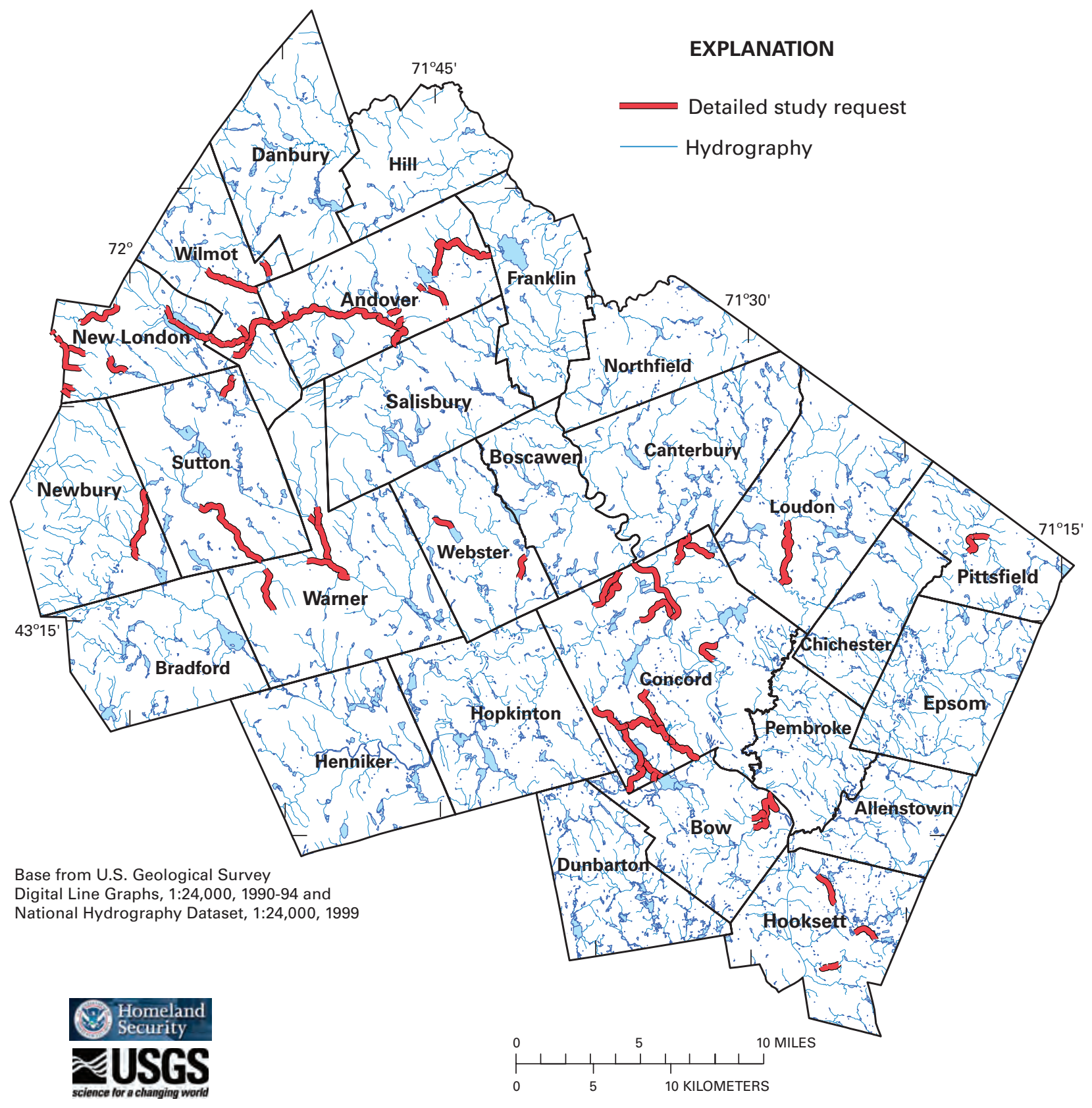

Figure 4. Merrimack County, New Hampshire, stream final coverage. 


\section{Section 3. Options for Future Mapping and Digital Terrain Model Preparation}

\section{Mapping Requirements}

This section provides an assessment of the costs and benefits of utilizing the data cataloged in the previous section for the preparation of DFIRMs for Merrimack County. Options are presented for using these data sets in various combinations and supplementing them with new data sets.

DFIRMs are produced from the following three broad categories of geospatial data: (1) Base Map, (2) Digital Terrain Model (DTM), and (3) Flood Insurance Risk Zones. The spatial accuracy of each of these three categories is fixed by the specifications contained in the "Guidelines and Specifications for Flood Hazard Mapping Partners,” April 2003 (Federal Emergency Management Agency, 2004).

- Base Maps: Base maps (1998 DOQs) are being acquired from NH GRANIT and will be used by FEMA as the background to the flood insurance risk zones shown on the DFIRMs.

- DTMs: DTMs are used in conjunction with H\&H models to interpret the limits of flood insurance risk zones.

- Flood Insurance Risk Zones: Geographic boundaries produced by FEMA.

\section{Base Map}

Base maps are defined in the "Guidelines and Specifications" as the "map of the community that depicts cultural features (for example, roads, railroad, bridges, dams, and culverts), drainage features, and corporate limits." Depending on the source of the base map, the specific features found on DFIRMs may include the following data and features:

- Roads: centerlines, edge-of-pavement, right-of-way, names.

- Railroads: names.

- Bridges: names.

- Flood Control Structures: headwall, dam, levee, names.

- Airport Boundaries: names.

- Rivers: centerlines, banks, names.

- Streams: names.

- Lakes: names.

- Political Boundaries: county, municipality, special districts, wards, military reservations, Native American lands, names.

- Land Use: parks, individual land parcels, names.

The "Guidelines and Specifications" specify "absolute horizontal accuracy" for base map features to establish horizontal accuracy for the position of the digital data set to its actual location on the earth's surface. The horizontal accuracy is specified as a statistical error distribution at the 95-percent confidence level and is specified in the "Guidelines and Specifications" as a function of finished map scale, as shown in table 4: 
Table 4. FIRM Horizontal Accuracy.

[FIRM, Flood Insurance Rate Map]

\begin{tabular}{lc}
\hline FIRM map scale & $\begin{array}{c}\text { Absolute horizontal accuracy at } \\
\text { the 95-percent confidence level, } \\
\text { in feet }\end{array}$ \\
\hline 1 in $=500 \mathrm{ft}$ & 19.0 \\
1 in $=1,000 \mathrm{ft}$ & 38.0 \\
1 in $=2,000 \mathrm{ft}$ & 45.6 \\
\hline
\end{tabular}

\section{Digital Terrain Models}

FEMA typically develops DTMs for the production of DFIRMS as they are not widely available at the accuracies required by FEMA. The DTMs are used in conjunction with $\mathrm{H} \& \mathrm{H}$ models to interpret flood boundaries and can be used by the community for many purposes other than flood management. DTMs represent terrain with irregularly spaced spot elevations $(\mathrm{x}, \mathrm{y}, \mathrm{z})$ and breaklines that indicate changes in ground slope at features such as the toe or top of channel banks or ridge lines. These data sets are generally photogrametrically compiled by a mapping contractor from stereo photos and utilized in the form of a Triangulated Irregular Network (TIN) or a DEM. A DEM uses a regular grid, or raster, spacing of $(\mathrm{x}, \mathrm{y}, \mathrm{z})$ points to represent the land surface. Each grid cell is assigned an average elevation to represent the elevation of the ground that is covered by the grid cell. A DEM represents the terrain surface with a mesh of regularly spaced points, whereas a TIN uses contiguous triangular planes.

Federal Emergency Management Agency (2004) "Guidelines and Specifications" identify the following four types of DTMs: (1) Digital contours, (2) DEMs, (3) Mass points and breaklines, and (4) TIN. Each of these models can be created from the other and their use is application dependent.

Under FEMA guidelines, the allowable DTMs are as follows:

1. Digital contours: continuous, nonintersecting lines of equal elevation separated by a specified elevation interval.

2. DEM: $\mathrm{x}, \mathrm{y}$, and $\mathrm{z}$ coordinates of regularly spaced points that form a grid.

3. Mass Points and Breaklines: $\mathrm{x}, \mathrm{y}$, and $\mathrm{z}$ coordinates of irregularly spaced points.

4. TIN: contiguous triangles with $\mathrm{x}, \mathrm{y}$, and $\mathrm{z}$ values at the vertices and faces with slope and aspect.

The "Guidelines and Specifications" specify what is referred to as "absolute vertical accuracy" for DTMs, which relates the elevation of the land surface in the digital data set to its actual elevation relative to a specific vertical datum. The National Standard for Spatial Data Accuracy (NSSDA) is specified as a statistical error distribution at the 90- and 95-percent confidence level as a function of the specified contour interval as shown in table 5 . 
Table 5. National Standard for Spatial Data Accuracy.

[NSSDA, National Standard for Spatial Data Accuracy, all values are in feet]

\begin{tabular}{ccc}
\hline Contour interval & $\begin{array}{c}\text { NSSDA } \\
\text { 90-percent confidence interval }\end{array}$ & $\begin{array}{c}\text { NSSDA } \\
\text { 95-percent confidence interval }\end{array}$ \\
\hline 2 & 1 & 1.2 \\
4 & 2 & 2.4 \\
\hline
\end{tabular}

Contouring and DEMs are not printed on DFIRMS so their vertical accuracy is not labeled on the DFIRMS, but it is recorded in the metadata of elevation datasets used for $\mathrm{H} \& \mathrm{H}$ modeling.

\section{Flood Insurance Risk Zones}

Flood insurance risk zones are created by FEMA to set insurance rates and manage the floodplain. Flood insurance risk zone accuracy requirements are not specified in the Guidelines and Specifications but can be described in terms of the combined accuracies of the base map, DTM, and the hydrology and hydraulic simulation models.

\section{Suitability of the Available Data}

The following section provides a summary of the suitability of the base map and DTM available for Merrimack County, N.H., from the appropriate community, county, and state resources. The USGS and NH GRANIT can provide digital data base mapping data for Merrimack County that meets FEMA requirements for DFIRM production. Neither USGS nor NH GRANIT has elevation data suitable for hydraulic modeling and communities were contacted to find topographic or elevation data suitable for hydraulic modeling (for example, 2-ft or 4-ft contours).

\section{Community Data Resources}

The City of Hooksett, N.H., and towns of Pembroke, Bow and Loudon, N.H., have 2-foot contourinterval data available for purchase through Holden Engineering (Peter Holden, Holden Engineering and Surveying, Inc., oral commun., September 6, 2005). The City of Concord also has 2-ft contour data available. These data are believed to meet FEMA requirements. No other community sources of digital elevation data for hydraulic modeling or FEMA flood mapping were located.

\section{County Data Resources}

Merrimack County does not contain suitable data for DFIRM use. Towns in Merrimack County are within the planning area of three planning commissions. These planning commissions include the Southern New Hampshire Regional Planning Commission, Central New Hampshire Regional Planning Commission, and Upper Valley Lake Sunapee Regional Planning Commission. The planning commissions did not have suitable data for DFIRM use. 


\section{Base Map}

NH GRANIT maintains data layers including features such as roads, streams, and political boundaries. Base map layers maintained by NH GRANIT include features such as roads, streams, and political boundaries. Base map data layers have been acquired from a variety of sources including the USGS data and represent many of the feature types found on USGS topographic maps. More recently developed data were derived from the digital orthophotos providing improved base map accuracy.

There are three base map sources available (table 6). These include the USGS DOQs (1:12,000; 1998, 1992) and NAIP Aerial Photographs $(1: 40,000 ; 2003)$. Existing coverages maintained by NH GRANIT can be linked to or viewed at the following Web site: http://www.granit.sr.unh.edu

Table 6. Currently available high resolution orthophotography for Merrimack County.

[USGS, U.S. Geological Survey; DOQQ, Digital Orthophoto Quarter Quad; B\&W, Black and White; NAIP, National Agricultural Imagery Program, NH GRANIT, New Hampshire Geographically Referenced Analysis and Information Transfer System]

\begin{tabular}{lllll}
\hline \multicolumn{1}{c}{ Item } & \multicolumn{1}{c}{ Source } & Date & Resolution & Coverage \\
\hline USGS DOQQ B\&W & USGS & 1998,1992 & 1.0 meter pixel & Statewide \\
NAIP 2003 Color & NH GRANIT, NAIP & 2003 & 1.0 meter pixel & Statewide \\
\hline
\end{tabular}

USGS Digital Ortho Quarter Quads (DOQQs) are available for all of Merrimack County. The DOQQs are FEMA's default standard for the base map. The accuracy and quality of the DOQQs meets National Map Accuracy Standards at 1:12,000 scale for 3.75-minute quarter quadrangles, plus or minus $33.33 \mathrm{ft}$ or $10 \mathrm{~m}$. For Merrimack County, the DOQQ orthophotos are dated 1998 and are 1.0-m resolution.

The NAIP 2003 color orthophotos were created by the Aerial Photography Field Office (APFO) of the U.S. Department of Agriculture (USDA) and processed by NH GRANIT to (1) standardize the exterior "nodata" values; (2) re-project the data into New Hampshire State Plane Feet (North American Datum of 1983 (NAD 83)); (3) tile the data to 15-minute quadrangles to facilitate distribution; and (4) re-compress the data to MrSID Generation 3 format. The source product is 1-m ground sample distance (GSD) DOQQs from the National Digital Ortho Program (NDOP). The imagery may contain as much as 10-percent cloud cover per source photograph.

\section{Digital Terrain Model}

NH GRANIT has the DEM USGS National Elevation Dataset (NED) available for download. NH GRANIT extracted the NED and re-projected the files into NAD 83. The data are based on USGS 7.5 minute DEMs (30m x 30m square grids). The DEMs were derived from USGS 1:24000 and 1:25000 quadrangle maps.

\section{Flood Insurance Risk Zones}

FEMA flood insurance rate 100- and 500-year flood zones are being converted to digital data layers by NH GRANIT for each community participating in the NFIP in New Hampshire. These datasets were developed by direct digitization of FIRM maps using data registration techniques that produced the best-fit registration to community boundaries or other suitable features. 


\section{Mapping Options}

The following section provides a summary of the potential options for developing base maps, DTMs, and flood insurance risk zones.

\section{Base Map}

Three base map options are presented for consideration:

1. Use existing USGS DOQQs from 1998 and 1992.

2. Use NAIP 2003, 1.0-m resolution color orthophotos.

3. Produce new vector data.

The recommended option for DFIRM production in Merrimack County is option \#1

\section{Digital Terrain Model}

There are no DTM data available that meet FEMA requirements for Merrimack County with the exception of 2-ft contour interval for Concord, N.H., and data created by Holden Engineering in select areas of Hooksett, Pembroke, Bow, and Loudon (Peter Holden, Holden Engineering and Surveying, Inc., oral commun., September 6, 2005).

DTM development options include (1) obtaining countywide DTM data that covers all communities and (2) obtaining DTM data only for selected floodplain areas as needed to support a detailed study, limited detailed study, restudy or re-delineation of flood-hazard areas.

The estimated costs of obtaining new DTM data is shown in table 7. These costs are based on the information determined by Camp, Dresser, and McKee, Inc. (2004) in their 2005 Scoping Report for Rutland County, Vermont. The estimates include the cost of the LiDAR (Light Detection and Ranging) imaging system work and the associated aerial photography work needed to create break line data.

Table 7. Estimate of costs to obtain Digital Terrain Model data (2-ft contours).

\begin{tabular}{ccr}
\hline $\begin{array}{c}\text { Area } \\
\text { (square miles) }\end{array}$ & $\begin{array}{c}\text { Unit cost } \\
\text { (\$ per square mile) }\end{array}$ & Estimated cost \\
\hline 20 & 5,000 & $\$ 100,000$ \\
50 & 3,000 & $\$ 150,000$ \\
75 & 2,250 & $\$ 168,750$ \\
100 & 2,000 & $\$ 200,000$ \\
935 & 1,250 & $\$ 1,168,750$ \\
\hline
\end{tabular}

Obtaining DTM data on a countywide basis is expensive. Most of the acquired data would be outside of the floodplain and not needed for hydraulic analysis. Two-foot contour data are available for select locations in Hooksett, Pembroke, Bow, and Loudon, N.H., from Holden Engineering and Surveying, Inc. (Peter Holden, Holden Engineering and Surveying, Inc., oral commun., September 6, 2005). If FEMA obtains new DTM data for selected areas as needed, it would be most cost effective to consolidate areas, where possible, and optimize flights, to reduce the unit costs. 


\section{Flood Insurance Risk Zones}

The response from communities in Merrimack County, New Hampshire was mixed regarding the accuracy of the flood insurance risk zones as shown on the existing panels. The most common comment by community representatives was that a better base map is needed to allow easier determination of where the risk zone boundaries are relative to the existing features such as roads and buildings.

\section{Section 4. Hydrologic and Hydraulic Restudy Needs and Prioritization}

This section summarizes the mapping needs prioritization process and presents the prioritization results based on community input as well as data obtained from other sources including MNUSS and LOMCs.

\section{Mapping Needs}

Based on community input, mapping needs included comments that no new studies were needed, floodplain boundaries are delineated incorrectly, the existing detailed study area needs to be extended, and remapping is needed.

\section{Prioritization Process}

DFIRM data are available for Merrimack County; however, the DFIRM data received on October 15, 2005, and entered into WISE, has not been Quality Assurance/Quality Control checked.

The data collected from the state and community meetings and MNUSS was entered into the WISE scoping tool. The data then were exported out of WISE and put into a spreadsheet to score each stream segment based on the relative importance of the following factors:

- Community population density.

- Population change (growth).

- Age of effective flood insurance study.

- Significant areas (as defined by the community).

- Existing or proposed development since the FIS.

- Presence of LOMAs/LOMRs.

- Priority (as assigned by community).

- Ranking of importance within the community (community defined).

The prioritization of the flooding sources was based on a number of factors specific to Merrimack County and is shown in table 8 . 
Table 8. Community flooding source prioritization.

[FIS, Flood Insurance Study; LOMCs, Letters of Map Changes]

\begin{tabular}{|c|c|c|c|c|c|}
\hline \multicolumn{2}{|c|}{ Community population density } & \multicolumn{2}{|c|}{ 1990-2000 percent population growth } & \multicolumn{2}{|c|}{ Year since most recent FIS } \\
\hline Range & Value & Range & Value & Range & Value \\
\hline$>1,000$ & 10 & $>50$ & 10 & $<1980$ & 10 \\
\hline 90-999 & 8 & $40-49$ & 8 & 1980-1984 & 8 \\
\hline $80-89$ & 6 & $30-39$ & 6 & $1985-1989$ & 6 \\
\hline $60-79$ & 4 & $20-29$ & 4 & 1990-1994 & 4 \\
\hline $30-59$ & 2 & $10-19$ & 2 & 1995-1999 & 2 \\
\hline $10-29$ & 1 & $5-9$ & 1 & 2000-2004 & 1 \\
\hline$<9$ & 0 & $<4$ & 0 & 2005 & 0 \\
\hline \multicolumn{2}{|c|}{$\begin{array}{c}\text { Significant areas } \\
\text { (as defined by the community) }\end{array}$} & \multicolumn{2}{|c|}{$\begin{array}{l}\text { Existing or proposed development } \\
\text { since FIS }\end{array}$} & \multicolumn{2}{|c|}{ Presence of LOMCs } \\
\hline Range & Value & Range & Value & Range & Value \\
\hline Yes & 5 & Yes & 5 & Yes & 5 \\
\hline No & 0 & No & 0 & No & 0 \\
\hline \multicolumn{2}{|c|}{ Community priority } & \multicolumn{2}{|c|}{ Community ranking } & & \\
\hline Range & Value & Range & Value & & \\
\hline High & 20 & 1 & 10 & & \\
\hline Medium & 10 & 2 & 8 & & \\
\hline \multirow[t]{2}{*}{ Low } & 0 & 3 & 6 & & \\
\hline & & $>4$ & 4 & & \\
\hline
\end{tabular}

\section{Prioritization Results}

The sum of the score for the parameters listed in table 8 was used to determine the final score for each stream and flooding source. The list of prioritized flooding sources is provided in appendix D.

Non-Participating Community - Dunbarton

The Town of Dunbarton is not currently in the NFIP. However, community representatives stated that the town has no flooding sources of concern. 


\section{Section 5. Recommendations and Schedule}

This section presents flood-mapping recommendations to meet the mapping needs described in previous sections.

\section{Mapping Recommendations}

FEMA's goal is to develop updated DFIRMs and FISs for Merrimack County, New Hampshire. The County has an area of approximately $935 \mathrm{mi}^{2}$ and encompasses 27 cities and towns.

Mapping Options

Mapping can be categorized based on the level of detail and required study effort to create or update flood-hazard zones.

- Baseline-DFIRM only: The most economical method of creating a countywide DFIRM is through digitizing flood-hazard information from the effective FIRMs and FISs onto new mapping. This baseline option is currently being undertaken by NH GRANIT.

- Redelineation: Detailed topography (2-ft contour interval) is available in Hooksett, Pembroke, Bow, Loudon, and Concord. The flood-hazard information from the effective FIRMs and FISs can be redelineated onto new topography and base mapping as it becomes available.

- Limited Detailed Study: Automated tools are used to produce digital information. This assumes new field surveys for structures but, no new field surveys for cross-sections are needed and that the existing hydraulic model can be used.

- Detailed Study: Can be performed to develop the digital information, including field surveyed cross-sections and structures. Since this is the most expensive type of study that FEMA can perform, the extent of the detailed study may be limited.

\section{Project Alternatives}

Costs can be reduced by cutting back on the level of effort for the H\&H analyses and(or) reducing the number of DFIRM panels. Alternative H\&H options that would help FEMA to reduce costs include reducing the study scope from a detailed study to a limited detail study or redelineation of current flood information only. Reducing the number of DFIRM panels by altering the mix of panel scales would lower the total panel count and reduce the estimated DFIRM production cost.

\section{Schedule}

The project schedule will vary depending on the final scope of the work. Detailed and Limited Detail Restudy and DFIRM production can be completed in 24 months, plus the time required for post preliminary processing, which may be completed in about 6 months for a total of 30 months. 


\section{Selected References}

Camp, Dresser, and McKee, Inc., 2004, Flood insurance study needs in the Blackstone River basin in Providence County, Rhode Island and Worcester County, Massachusetts: Contract No. EME-2003-CO-0340, Task Order T001, Task 1, February 2004, variously paged.

Camp, Dresser, and McKee, Inc., 2005, Flood insurance study needs in Rutland County, Vermont: Contract No. EME-2003-CO-0340, variously paged.

Federal Emergency Management Agency, 2004, Guidelines and specifications for flood-hazard ampping partners, accessed online January 10, 2006, at http://www.fema.gov/plan/prevent/fhm/gs_main.shtm

New Hampshire GRANIT (Geographically Referenced ANalysis and Information Transfer system), 2006, accessed online January 12, 2006, at http://www.granit.sr.unh.edu/

University of New Hampshire, 2005, Carsey Institute, accessed online September 28, 2005, at http://www.nneindicators.unh.edu/ShowOneRegion.asp?IndicatorID=1\&FIPS=33013.

Watershed Concepts, a Division of Hayes, Seay, Mattern and Mattern, Watershed Information System (WISE), version 2.0.9, 2005. 


\section{Appendix A. Summary of Letters of Map Change (LOMC) Data in Merrimack County}


Table A-1. Summary of LOMC data in Merrimack County.

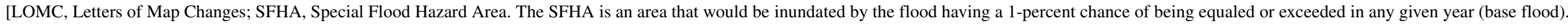
LOMA, Letter of Map Amendment; LOMR-FW, Letter of Map Revision Floodway; LOMA-OAS, Letter of Map Amendment Out-As-Shown]

\begin{tabular}{|c|c|c|c|c|c|c|c|c|c|c|}
\hline Community & $\begin{array}{l}\text { LOMC } \\
\text { type }\end{array}$ & Case number & $\begin{array}{l}\text { Effective } \\
\text { date }\end{array}$ & Flooding source & Address & $\begin{array}{l}\text { Property } \\
\text { latitude }\end{array}$ & $\begin{array}{c}\text { Property } \\
\text { longi- } \\
\text { tude }\end{array}$ & $\begin{array}{l}\text { Removed from } \\
\text { SFHA (1) }\end{array}$ & $\begin{array}{l}\text { New flood } \\
\text { zone }\end{array}$ & Notes \\
\hline Concord, N.H. & LOMA & $02-01-0622 \mathrm{~A}$ & $6 / 26 / 2002$ & Bela Brook & Birchdale Road & 43.162 & -71.583 & Portion of property & $\mathrm{X}$ & Portions remain in the SFHA; Zone A. \\
\hline Danbury, N.H. & LOMA & 00-01-0376A & $6 / 20 / 2000$ & $\begin{array}{l}\text { Unnamed tributary } \\
\text { to Walker Brook }\end{array}$ & Walker Brook Road & 43.502 & -71.913 & Structure & $\mathrm{C}$ & Portions remain in the SFHA; Zone A. \\
\hline Epsom, N.H. & LOMA & 03-01-1318A & $7 / 24 / 2003$ & Suncook River & 12 Nixon Street & 43.189 & -71.381 & Structure & $\mathrm{C}$ & Portions remain in the SFHA. \\
\hline Epsom, N.H. & $\begin{array}{l}\text { LOMR- } \\
\text { FW }\end{array}$ & $04-01-1202 \mathrm{~A}$ & $11 / 1 / 2004$ & Suncook River & $\begin{array}{l}1188 \text { Suncook Valley } \\
\text { Highway }\end{array}$ & 43.181 & -71.391 & Property & $\mathrm{C}$ & Inadvertant inclusion in Floodway 2. \\
\hline Franklin, N.H. & LOMA & 02-01-0886A & $5 / 8 / 2002$ & Webster Lake & 39 Lake Shore Drive & 43.467 & -71.695 & Structure & $\mathrm{C}$ & Portions remain in the SFHA. \\
\hline Hill, N.H. & $\begin{array}{l}\text { LOMA- } \\
\text { OAS }\end{array}$ & 02-01-0216A & $3 / 22 / 2002$ & Pemigewaset River & 22 Route $3 \mathrm{~A}$ & 43.516 & -71.699 & Factory/2 buildings & $\mathrm{C}$ & Portions remain in the SFHA; Zone A. \\
\hline Hill, N.H. & LOMA & 02-01-0216A & $3 / 22 / 2002$ & Pemigewaset River & 22 Route $3 \mathrm{~A}$ & 43.516 & -71.699 & House/barn & $\mathrm{C}$ & Portions remain in the SFHA; Zone A. \\
\hline Loudon, N.H. & LOMA & 03-01-0902A & $4 / 21 / 2003$ & Soucook River & 11 Route 129 & 43.287 & -71.465 & Residential structure & $\mathrm{C}$ & Portions remain in the SFHA; Zone A. \\
\hline Loudon, N.H. & LOMA & $99-01-486 \mathrm{~A}$ & 3/16/1999 & Soucook River & 78 Goshen Drive & 43.303 & -71.465 & Structure & $\mathrm{C}$ & Portions remain in the SFHA. \\
\hline Loudon, N.H. & LOMA & $99-01-1402 \mathrm{~A}$ & $2 / 17 / 2000$ & Soucook River & 25 Staniels Road & 43.257 & -71.455 & Portion of property & $\mathrm{C}$ & Portions remain in the SFHA; Zone A. \\
\hline New London, N.H. & LOMA & 02-01-0842A & $8 / 2 / 2002$ & Messer Pond & 3 White Pine Lane & 43.402 & -72.008 & Structure & $\mathrm{C}$ & Portions remain in the SFHA; Zone A. \\
\hline New London, N.H. & LOMA & 03-01-1062A & $5 / 8 / 2003$ & $\begin{array}{l}\text { Unnamed flooding } \\
\text { source }\end{array}$ & 9 Scythe Shop Road & 43.419 & -71.932 & Residential structure & $\mathrm{C}$ & Portions remain in the SFHA; Zone A. \\
\hline Pembroke, N.H. & LOMA & 04-01-0584A & $2 / 5 / 2004$ & Suncook River & 730 Bachelder Road & 43.171 & -71.399 & Residential structure & $\mathrm{C}$ & Portions remain in the SFHA. \\
\hline Pittsfield, N.H. & LOMA & 00-01-0774A & $6 / 27 / 2000$ & Suncook River & 1 Lyford Hill Road & 43.307 & -71.331 & Structure & $\mathrm{C}$ & Portions remain in the SFHA. \\
\hline Sutton, N.H. & LOMA & 01-01-0052A & $11 / 14 / 2000$ & Warner River & Roby Road & 43.29 & -71.888 & Residential structure & $\mathrm{C}$ & Portions remain in the SFHA; Zone A. \\
\hline Sutton, N.H. & LOMA & 01-01-0144A & $12 / 19 / 2000$ & Lane River & 10 Dodge Hill Road & 43.318 & -71.934 & Structure & $\mathrm{C}$ & Portions remain in the SFHA; Zone A. \\
\hline Sutton, N.H. & LOMA & 01-01-0944A & $7 / 25 / 2001$ & Cascade Brook & 12 French Road & 43.393 & -71.912 & Residential structure & $\mathrm{C}$ & Portions remain in the SFHA; Zone A. \\
\hline Webster, N.H. & LOMA & 02-01-0354A & $2 / 8 / 2002$ & Beaverdam Brook & 1197 Long Street & 43.333 & -71.707 & Structure & $\mathrm{C}$ & Portions remain in the SFHA; Zone A. \\
\hline Webster, N.H. & LOMA & 02-01-0362A & $2 / 8 / 2002$ & Beaverdam Brook & 1178 Long Street & 43.332 & -71.707 & Structure & $\mathrm{C}$ & Portions remain in the SFHA; Zone A. \\
\hline Webster, N.H. & LOMA & 02-01-0364A & $2 / 8 / 2002$ & Beaverdam Brook & 50 Beaver Dam Drive & 43.335 & -71.708 & Structure & $\mathrm{C}$ & Portions remain in the SFHA; Zone A. \\
\hline Webster, N.H. & LOMA & 02-01-0350A & $2 / 8 / 2002$ & Beaverdam Brook & 40 Beaver Dam Drive & 43.334 & -71.708 & Structure & $\mathrm{C}$ & Portions remain in the SFHA; Zone A. \\
\hline Webster, N.H. & LOMA & 02-01-0358A & $2 / 8 / 2002$ & Beaverdam Brook & 30 Beaver Dam Drive & 43.334 & -71.707 & Structure & $\mathrm{C}$ & Portions remain in the SFHA; Zone A. \\
\hline Webster, N.H. & LOMA & 02-01-0738A & $3 / 11 / 2002$ & Beaverdam Brook & 29 Beaver Dam Drive & 43.334 & -71.708 & Garage & $\mathrm{C}$ & Portions remain in the SFHA; Zone A. \\
\hline Webster, N.H. & LOMA & 02-01-0360A & $2 / 8 / 2002$ & Beaverdam Brook & 20 Beaver Dam Drive & 43.333 & -71.707 & Structure & $\mathrm{C}$ & Portions remain in the SFHA; Zone A. \\
\hline Webster, N.H. & LOMA & 02-01-0356A & $2 / 8 / 2002$ & Beaverdam Brook & 29 Beaver Dam Drive & 43.334 & -71.708 & Residential structure & $\mathrm{C}$ & Portions remain in the SFHA; Zone A. \\
\hline Webster, N.H. & LOMA & 02-01-0344A & $2 / 8 / 2002$ & Beaverdam Brook & 17 Beaver Dam Drive & 43.333 & -71.708 & Structure & $\mathrm{C}$ & Portions remain in the SFHA; Zone A. \\
\hline Wilmot, N.H. & LOMA & 02-01-1238A & $7 / 12 / 2002$ & Chase Pond & 114 Quiet Cove Road & 43.417 & -71.913 & Structure & $\mathrm{C}$ & Portions remain in the SFHA; Zone A. \\
\hline Wilmot, N.H. & LOMA & 00-01-0224A & $3 / 3 / 2000$ & Chase Pond & Quiet Cove Road & 43.417 & -71.917 & Structure & $\mathrm{C}$ & Portions remain in the SFHA; Zone A. \\
\hline
\end{tabular}




\title{
Appendix B. Mapping Needs Update Support System (MNUSS) Needs Assessment Reports
}

\author{
Merrimack County, New Hampshire \\ MNUSS Needs Assessment Reports Summary Table
}

New Hampshire Mapping Needs in MNUSS

November 30, 2005 
Table B-1. Mapping Needs Update Support System (MNUSS) needs assessment reports summary.

\begin{tabular}{|c|c|c|c|c|c|}
\hline CID & Community name & Flood data update & Map maintenance & Pending & Resolved \\
\hline 330103 & Allenstown, Town of & 0 & 0 & 0 & 0 \\
\hline 330104 & Andover, Town of & 0 & 1 & 0 & 0 \\
\hline 330105 & Boscawen, Town of & 0 & 0 & 0 & 0 \\
\hline 330107 & Bow, Town of & 0 & 0 & 0 & 1 \\
\hline 330106 & Bradford, Town of & 0 & 0 & 0 & 0 \\
\hline 330108 & Canterbury, Town of & 0 & 0 & 0 & 0 \\
\hline 330109 & Chichester, Town of & 0 & 0 & 0 & 0 \\
\hline 330110 & Concord, City of & 0 & 0 & 0 & 0 \\
\hline 330111 & Danbury, Town of & 0 & 0 & 0 & 0 \\
\hline 330202 & Dunbarton, Town of & 0 & 0 & 0 & 0 \\
\hline 330112 & Epsom, Town of & 1 & 0 & 0 & 0 \\
\hline 330113 & Franklin, City of & 0 & 0 & 0 & 0 \\
\hline 330114 & Henniker, Town of & 1 & 1 & 0 & 0 \\
\hline 330214 & Hill, Town of & 0 & 0 & 0 & 0 \\
\hline 330115 & Hooksett, Town of & 4 & 1 & 0 & 0 \\
\hline 330116 & Hopkinton, Town of & 0 & 1 & 0 & 0 \\
\hline 330117 & Loudon, Town of & 0 & 0 & 0 & 0 \\
\hline 330230 & New London, Town of & 0 & 0 & 0 & 0 \\
\hline 330226 & Newbury, Town of & 0 & 0 & 0 & 0 \\
\hline 330118 & Northfield, Town of & 0 & 0 & 0 & 0 \\
\hline 330119 & Pembroke, Town of & 0 & 1 & 0 & 0 \\
\hline 330120 & Pittsfield, Town of & 0 & 0 & 0 & 0 \\
\hline 330121 & Salisbury, Town of & 0 & 1 & 0 & 0 \\
\hline 330122 & Sutton, Town of & 0 & 0 & 0 & 0 \\
\hline 330123 & Warner, Town of & 0 & 0 & 0 & 0 \\
\hline 330236 & Webster, Town of & 0 & 0 & 0 & 0 \\
\hline \multirow[t]{2}{*}{330124} & Wilmot, Town of & 0 & 0 & 0 & 0 \\
\hline & Totals & 6 & 6 & 0 & 0 \\
\hline
\end{tabular}




\begin{tabular}{|c|c|c|c|}
\hline Community: & ANDOVER, TOWN OF & CID: & 330104 \\
\hline County: & MERRIMACK COUNTY & State: & New Hampshire \\
\hline \multicolumn{4}{|c|}{ NEED DETAIL INFORMATION } \\
\hline Need ID: & 100000000010603 & Entered By: & Chuck Wood \\
\hline \multirow[t]{4}{*}{ Source: } & FEMA 5-year letter & Date: & 03/16/1998 \\
\hline & & & FEMA \\
\hline & & & $3 / 16 / 98$ \\
\hline & MAINTENANCE & Need Types: & Add streets to panel \\
\hline
\end{tabular}

\section{PANELS AFFECTED BY THE NEED}

\section{ORIGIN OF NEED INFORMATION}

$\begin{array}{llll}\text { Entity: } & \text { TOWN OF ANDOVER } & \text { Phone: } & 6037355332 \quad \text { Ext: } \\ \text { Last Name: } & \text { STETSON } & \text { First Name: } & \text { MARK } \\ \text { Address 1: } & \text { P.O. BOX61 } & \text { Title: } & \text { TOWN ADMINISTRATOR } \\ \text { Address 2: } & \text { Unspecified } & \text { Email: } & \text { Unspecified } \\ \text { City: } & \text { ANDOVER } & \text { Fax: } & \text { Unspecified } \\ \text { State: } & \text { NH } & \text { Zip: } & 03216-0061\end{array}$

\section{NEED NOTES AND COMMENTS}

There are no notes for this need. 


\begin{tabular}{|c|c|c|c|}
\hline Community: & BOW, TOWN OF & CID: & 330107 \\
\hline County: & MERRIMACK COUNTY & State: & New Hampshire \\
\hline
\end{tabular}

\begin{tabular}{llll}
$\begin{array}{l}\text { NEED DETAIL INFORMATION } \\
\text { Need ID: }\end{array}$ & 100000000010565 & \\
Source: & FEMA Future File & Entered By: & Chuck Wood \\
& & Date: & $06 / 08 / 1999$ \\
& & \\
& & $6 / 8 M / 99$ \\
& & \\
\hline & RIVERINE & Need Types: & Changes to BFEs \\
Flooding Source: & MERRIMACK RIVER & & \\
\hline & Resolved & & \\
Resolved Date: & $11 / 20 / 00$ & Type of map action: & T-19 (Contracted Study)
\end{tabular}

\section{NEEED FLOODPLAIN DATA}

Anticipated BFE Change:

Increased By Between 1 and 5 feet

Length of Study:

5.87 miles

Average Width of Floodplain: 2500 feet

Location of Floodplain:

$3301070002 D(11 / 20 / 2000)$

\section{ORIGIN OF NEED INFORMATION}

Entity:

Last Name:

Address 1:

Address 2:

City:

State:
D\&D FUTURE FILE

Unspecified

Unspecified

Unspecified

Unspecified

Unspecified
Phone:

First Name:

Title:

Email:

Fax:

Zip:

Unspecified
Unspecified
Unspecified
Unspecified
Unspecified
Unspecified

Ext:

Unspecified

Unspecified

\section{NEED NOTES AND COMMENTS}

$\begin{array}{lll}\text { Date } & \text { Entered By } & \text { Note } \\ \text { 06/08/1999 } & \text { Chuck Wood } & \begin{array}{l}\text { NEW STUDY IS NEEDED, FIRM IS NOT ACCURATE AND AREA HAS SEEN } \\ \text { A RECENT BOOM IN DEVELOPMENT. }\end{array} \\ \text { 06/08/1999 } & \text { Chuck Wood } & \begin{array}{l}\text { NEW STUDY IS NEEDED, FIRM IS NOT ACCURATE AND AREA HAS SEEN } \\ \text { A RECENT BOOM IN DEVELOPMENT. }\end{array}\end{array}$




$\begin{array}{llll} & & & \\ \text { Community: } & \text { EPSOM, TOWN OF } & \text { CID: } & 330112 \\ \text { County: } & \text { MERRIMACK COUNTY } & \text { State: } & \text { New Hampshire }\end{array}$

\begin{tabular}{|c|c|c|c|}
\hline \multicolumn{4}{|c|}{ NEED DETAIL INFORMATION } \\
\hline Need ID: & 100000000010570 & Entered By: & Chuck Wood \\
\hline \multirow[t]{4}{*}{ Source: } & FEMA 5-year letter & Date: & 09/09/1997 \\
\hline & & & FEMA \\
\hline & & & 9/9/97 \\
\hline & RIVERINE & Need Types: & Changes to hydraulic analysis \\
\hline \multirow[t]{2}{*}{ Flooding Source: } & NORTHWOOD LAKE & & \\
\hline & Existing & & \\
\hline
\end{tabular}

\section{NEED FLOODPLAIN DATA}

\section{Anticipated BFE Change:}

Length of Study:

Average Width of Floodplain:

Location of Floodplain:
Decreased By Less Than 1 foot

1.86 miles

80 feet

$\begin{array}{lllll} & & & & \\ \text { Entity: } & \text { EPSOM, TOWN OF [TOWN GOVERNMENT] } & \text { Phone: } & 603736441 \quad \text { Ext: } & \text { Unspecified } \\ \text { Last Name: } & \text { BICKFORD } & \text { First Name: } & \text { ALFRED G. } & \\ \text { Address 1: } & \text { P.O. BOX 10 } & \text { Title: } & \text { ZONING OFFICER } \\ \text { Address 2: } & \text { Unspecified } & \text { Email: } & \text { Unspecified } \\ \text { City: } & \text { EPSOM } & \text { Fax: } & 6037368539 \\ \text { State: } & \text { NH } & \text { Zip: } & \text { 03234- }\end{array}$

\section{NEED NOTES AND COMMENTS}

There are no notes for this need. 


$\begin{array}{llll}\text { Community: } & \text { HENNIKER, TOWN OF } & \text { CID: } & 330114 \\ \text { County: } & \text { MERRIMACK COUNTY } & \text { State: } & \text { New Hampshire }\end{array}$

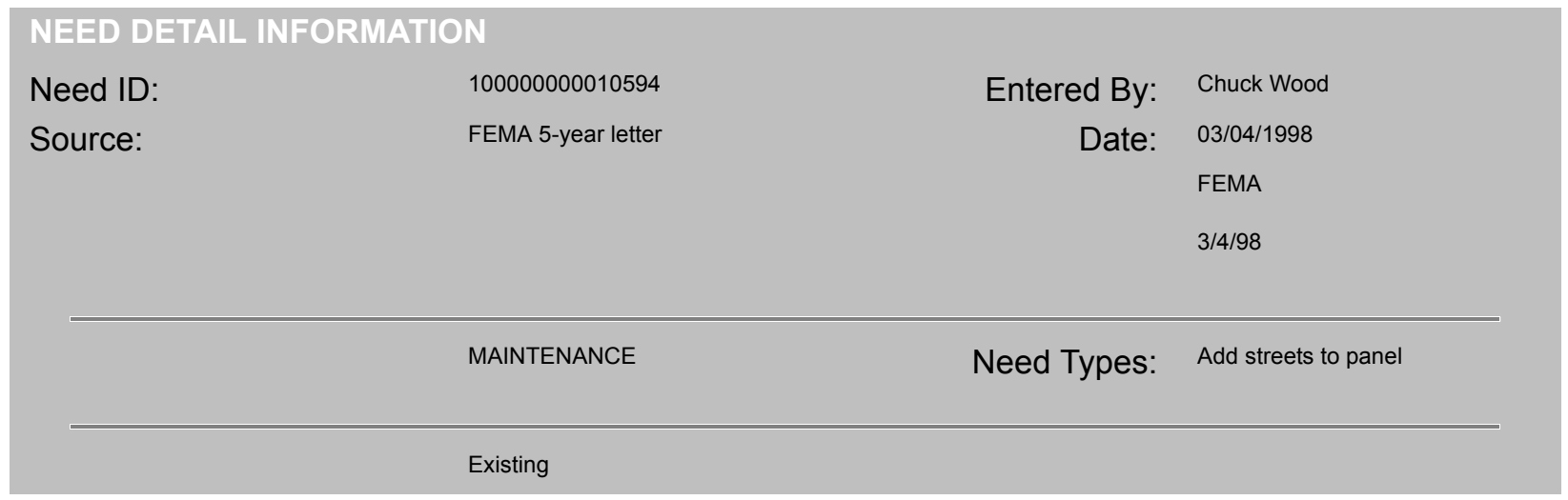

\section{PANELS AFFECTED BY THE NEED}

$\begin{array}{lllll}\text { Entity: } & \text { HENNIKER, TOWN OF [TOWN GOVERNMENT] } & \text { Phone: } & 6034283221 & \text { Ext: } \\ \text { Last Name: } & \text { CLARK } & \text { First Name: } & \text { KELLY A. } & \\ \text { Address 1: } & \text { 2 DEPOT HILL ROAD } & \text { Title: } & \text { TOWN ADMINISTRATOR } \\ \text { Address 2: } & \text { Unspecified } & \text { Email: } & \text { Unspecified } \\ \text { City: } & \text { HENIKER } & \text { NH } & \text { Fax: } & 6034284366 \\ \text { State: } & & \text { Zip: } & 03242- & \end{array}$

\section{NEED NOTES AND COMMENTS}

There are no notes for this need. 


$\begin{array}{llll}\text { Community: } & \text { HENNIKER, TOWN OF } & \text { CID: } & 330114 \\ \text { County: } & \text { MERRIMACK COUNTY } & \text { State: } & \text { New Hampshire }\end{array}$

\begin{tabular}{|c|c|c|c|}
\hline \multicolumn{4}{|c|}{ NEED DETAIL INFORMATION } \\
\hline Need ID: & 100000000010595 & Entered By: & Chuck Wood \\
\hline \multirow[t]{4}{*}{ Source: } & FEMA 5-year letter & Date: & 03/04/1998 \\
\hline & & & FEMA \\
\hline & & & $3 / 4 / 98$ \\
\hline & RIVERINE & Need Types: & Changes to hydrologic conditions \\
\hline Flooding Source: & UNNAMED ZONE A AREA & & \\
\hline
\end{tabular}

\section{NEEED FLOODPLAIN DATA}

Anticipated BFE Change:

Length of Study:

Average Width of Floodplain:

Location of Floodplain:
Increased By Greater Than 5 feet

2 miles

680 feet

$\begin{array}{lllll} & & & \\ & & & \\ & & & \\ & & & \\ & & & \\ & & & \\ \text { Entity: } & \text { HENNIKER, TOWN OF [TOWN GOVERNMENT] } & \text { Phone: } & 6034283221 \quad \text { Ext: Unspecified } \\ \text { Last Name: } & \text { CLARK } & \text { First Name: } & \text { KELLY A. } \\ \text { Address 1: } & \text { 2 DEPOT HILL ROAD } & \text { Title: } & \text { TOWN ADMINISTRATOR } \\ \text { Address 2: } & \text { Unspecified } & \text { Email: } & \text { Unspecified } \\ \text { City: } & \text { HENNIKER } & \text { Fax: } & \text { 6034284366 } \\ \text { State: } & \text { NH } & \text { Zip: } & & \\ & & & \end{array}$

\section{NEED NOTES AND COMMENTS}

There are no notes for this need. 


\begin{tabular}{|c|c|c|c|}
\hline Community: & HOOKSETT, TOWN OF & CID: & 330115 \\
\hline County: & MERRIMACK COUNTY & State: & New Hampshire \\
\hline
\end{tabular}

\begin{tabular}{|c|c|c|c|}
\hline Need ID: & 100000000029312 & Entered By: & Kara Deutsch \\
\hline \multirow[t]{5}{*}{ Source: } & State Implementation Plan & Date: & 09/30/2002 \\
\hline & & & Automatic (no FEMA validation) \\
\hline & & & $11 / 14 / 02$ \\
\hline & MAINTENANCE & Need Types: & Add streets to panel \\
\hline & Existing & & \\
\hline
\end{tabular}

\section{PANELS AFFECTED BY THE NEED}

$3301150015 \mathrm{C}(03 / 12 / 1982)$

$3301150010 \mathrm{C}(03 / 12 / 1982)$

$3301150020 \mathrm{C}(03 / 12 / 1982)$

$\begin{array}{llll}\text { ORIGIN OF NEED INFORMATION } & & \\ \text { Entity: } & \text { HOOKSETT PLANNING DEPARTMENT } & \text { Phone: } & \text { (603) 268-0279 } \\ \text { Last Name: } & \text { WATSON } & \text { First Name: } & \text { CHARLES } \\ \text { Address 1: } & \text { 16 MAIN STREET } & \text { Title: } & \text { TOWN PLANNER } \\ \text { Address 2: } & - & \text { Email: } & \text { cwatson@hooksett.org } \\ \text { City: } & \text { HOOKSETT } & \text { Fax: } & \text { (603) } 485-4423 \\ \text { State: } & \text { NH } & \text { Zip: } & 03106\end{array}$

\section{NEED NOTES AND COMMENTS}

There are no notes for this need. 


\begin{tabular}{|c|c|c|c|}
\hline Community: & HOOKSETT, TOWN OF & CID: & 330115 \\
\hline County: & MERRIMACK COUNTY & State: & New Hampshire \\
\hline
\end{tabular}

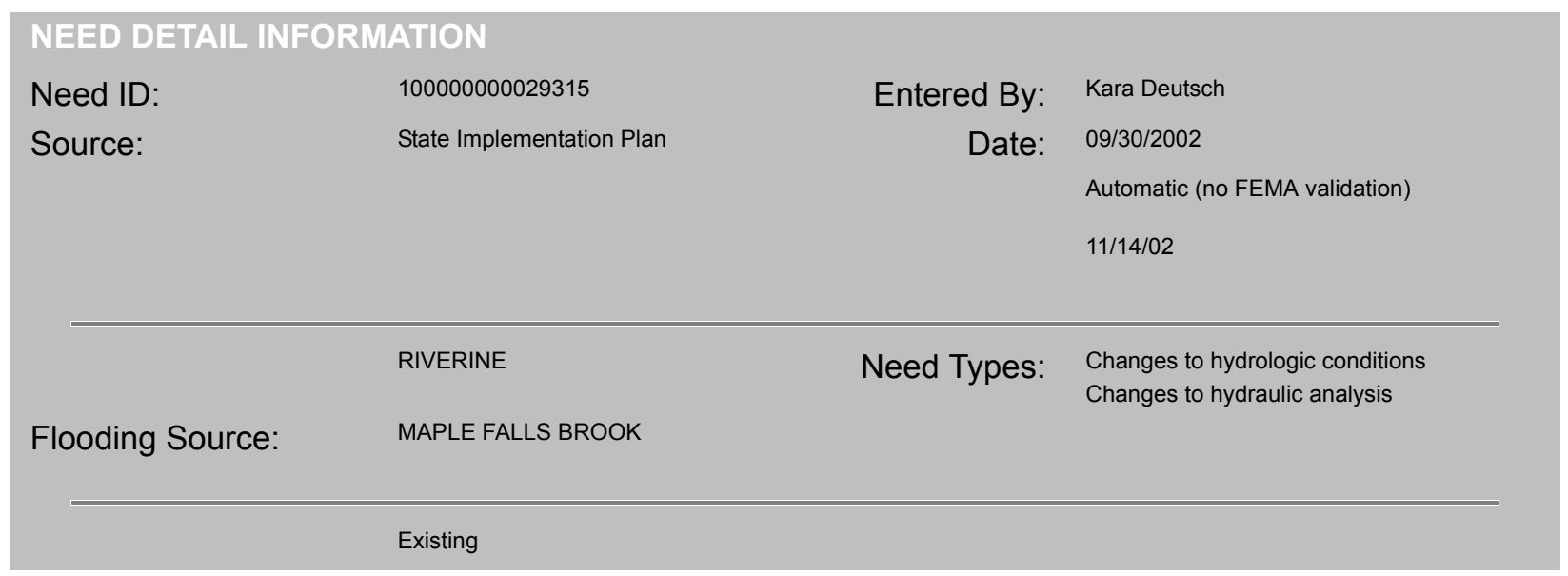

\section{NEED FLOODPLAIN DATA}

\section{Anticipated BFE Change:}

Length of Study:

Average Width of Floodplain:

Location of Floodplain:

Decreased By Less Than 1 foot

1.4 miles

500 feet

County boundary to Dubes Pond Dam.

\section{PANELS AFFECTED BY THE NEED}

\section{ORIGIN OF NEED INFORMATION}

$\begin{array}{lllll}\text { Entity: } & \text { HOOKSETT PLANNING DEPARTMENT } & \text { Phone: } & \text { (603) } 268-0279 & \text { Ext: } \\ \text { Last Name: } & \text { WATSON } & \text { First Name: } & \text { CHARLES } & \\ \text { Address 1: } & 16 \text { MAIN STREET } & \text { Title: } & \text { TOWN PLANNER } & \\ \text { Address 2: } & - & \text { Email: } & \text { cwatson@hooksett.org } & \\ \text { City: } & \text { HOOKSETT } & \text { Fax: } & \text { (603) } 485-4423 & \\ \text { State: } & \text { NH } & \text { Zip: } & 03106 & \end{array}$

\section{NEED NOTES AND COMMENTS}

\section{There are no notes for this need.}




\begin{tabular}{|c|c|c|c|}
\hline Community: & HOOKSETT, TOWN OF & CID: & 330115 \\
\hline County: & MERRIMACK COUNTY & State: & New Hampshire \\
\hline
\end{tabular}

\begin{tabular}{|c|c|c|c|}
\hline \multicolumn{4}{|c|}{ NEED DETAIL INFORMATION } \\
\hline Need ID: & 100000000029316 & Entered By: & Kara Deutsch \\
\hline \multirow[t]{4}{*}{ Source: } & State Implementation Plan & Date: & 09/30/2002 \\
\hline & & & Automatic (no FEMA validation) \\
\hline & & & $11 / 14 / 02$ \\
\hline & RIVERINE & Need Types: & Changes to hydrologic conditions \\
\hline \multirow[t]{2}{*}{ Flooding Source: } & DALTON BROOK & & \\
\hline & Existing & & \\
\hline
\end{tabular}

\section{NEEED FLOODPLAIN DATA}

\section{Anticipated BFE Change:}

Length of Study:

Average Width of Floodplain:

Location of Floodplain:

\author{
Decreased By Less Than 1 foot \\ 0.75 miles \\ 600 feet
}

Benton Road to Berry Hill Road.

\section{PANELS AFFECTED BY THE NEED}

\begin{tabular}{|c|c|c|c|c|}
\hline Entity: & HOOKSETT PLANNING DEPARTMENT & Phone: & (603) 268-0279 & Ext: \\
\hline Last Name: & WATSON & First Name: & CHARLES & \\
\hline Address 1: & 16 MAIN STREET & Title: & TOWN PLANNER & \\
\hline Address 2: & - & Email: & cwatson@hooksett.org & \\
\hline City: & HOOKSETT & Fax: & (603) $485-4423$ & \\
\hline State: & $\mathrm{NH}$ & Zip: & 03106 & \\
\hline
\end{tabular}

\section{NEED NOTES AND COMMENTS}

$\begin{array}{lll}\text { Date } & \text { Entered By } & \text { Note } \\ \text { 09/30/2002 } & \text { Kara Deutsch } & \text { Community believes flood boundary is inaccurate. }\end{array}$




$\begin{array}{llll}\text { Community: } & \text { HOOKSETT, TOWN OF } & \text { CID: } & 330115 \\ \text { County: } & \text { MERRIMACK COUNTY } & \text { State: } & \text { New Hampshire }\end{array}$

\begin{tabular}{|c|c|c|c|}
\hline \multicolumn{4}{|c|}{ NEED DETAIL INFORMATION } \\
\hline Need ID: & 100000000029313 & Entered By: & Kara Deutsch \\
\hline \multirow[t]{4}{*}{ Source: } & State Implementation Plan & Date: & 09/30/2002 \\
\hline & & & Automatic (no FEMA validation) \\
\hline & & & $11 / 14 / 02$ \\
\hline & RIVERINE & Need Types: & $\begin{array}{l}\text { Changes to hydrologic conditions } \\
\text { Changes to hydraulic analysis }\end{array}$ \\
\hline \multirow[t]{2}{*}{ Flooding Source: } & HEADS POND & & \\
\hline & Existing & & \\
\hline
\end{tabular}

\section{NEEED FLOODPLAIN DATA}

\section{Anticipated BFE Change:}

Length of Study:

Average Width of Floodplain:

Location of Floodplain:
Decreased By Less Than 1 foot

1.7 miles

800 feet

$\begin{array}{lllll}\text { ORIGIN OF NEED INFORMATION } & & & \\ \text { Entity: } & \text { HOOKSETT PLANNING DEPARTMENT } & \text { Phone: } & \text { (603) 268-0279 } & \text { Ext: } \\ \text { Last Name: } & \text { WATSON } & \text { First Name: } & \text { CHARLES } & \\ \text { Address 1: } & \text { 16 MAIN STREET } & \text { Title: } & \text { TOWN PLANNER } & \\ \text { Address 2: } & - & \text { Email: } & \text { cwatson@hooksett.org } & \\ \text { City: } & \text { HOOKSETT } & \text { Fax: } & \text { (603) } 485-4423 & \\ \text { State: } & \text { NH } & \text { Zip: } & 03106 & \end{array}$

\section{NEED NOTES AND COMMENTS}

\section{Date}

09/30/2002

\section{Entered By}

Kara Deutsch

\section{Note}

Currently Zone A. 


$\begin{array}{llll}\text { Community: } & \text { HOOKSETT, TOWN OF } & & \\ \text { County: } & \text { MERRIMACK COUNTY } & \text { CID: } & 330115 \\ & \text { State: } & \text { New Hampshire }\end{array}$

\begin{tabular}{|c|c|c|c|}
\hline \multicolumn{4}{|c|}{ NEED DETAIL INFORMATION } \\
\hline Need ID: & 100000000029314 & Entered By: & Kara Deutsch \\
\hline \multirow[t]{4}{*}{ Source: } & State Implementation Plan & Date: & 09/30/2002 \\
\hline & & & Automatic (no FEMA validation) \\
\hline & & & $11 / 14 / 02$ \\
\hline & RIVERINE & Need Types: & $\begin{array}{l}\text { Changes to hydrologic conditions } \\
\text { Changes to hydraulic analysis }\end{array}$ \\
\hline \multirow[t]{2}{*}{ Flooding Source: } & DUBES POND & & \\
\hline & Existing & & \\
\hline
\end{tabular}

\section{NEEED FLOODPLAIN DATA}

Anticipated BFE Change:

Length of Study:

Average Width of Floodplain:

Decreased By Less Than 1 foot

1.2 miles

1000 feet

Location of Floodplain:

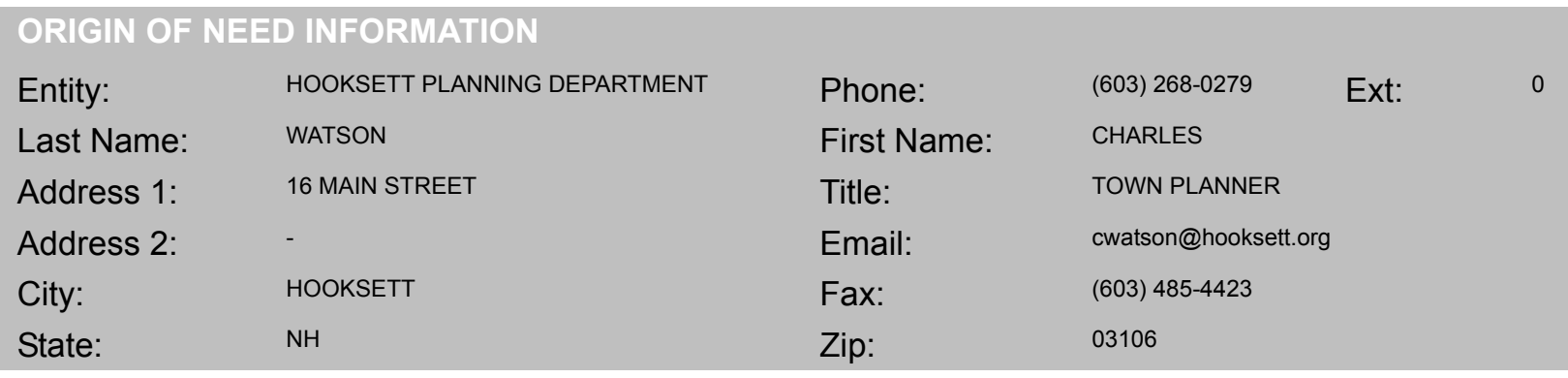

\section{NEED NOTES AND COMMENTS}

\section{Date}

09/30/2002

\section{Entered By}

Kara Deutsch

\section{Note}

Currently Zone A 


$\begin{array}{llll}\text { Community: } & \text { HOPKINTON, TOWN OF } & \text { CID: } & 330116 \\ \text { County: } & \text { MERRIMACK COUNTY } & \text { State: } & \text { New Hampshire }\end{array}$

\begin{tabular}{|c|c|c|c|}
\hline Need ID: & 100000000010631 & Entered By: & Chuck Wood \\
\hline \multirow[t]{5}{*}{ Source: } & FEMA Future File & Date: & 09/15/1998 \\
\hline & & & FEMA \\
\hline & & & 9/15/98 \\
\hline & MAINTENANCE & Need Types: & Align map panels \\
\hline & Existing & & \\
\hline
\end{tabular}

\section{PANELS AFFECTED BY THE NEED}

\begin{tabular}{|c|c|c|c|c|c|}
\hline Entity: & D\&D FUTURE FILE & Phone: & Unspecified & Ext: & Unspecified \\
\hline Last Name: & Unspecified & First Name: & Unspecified & & \\
\hline Address 1: & Unspecified & Title: & Unspecified & & \\
\hline Address 2: & Unspecified & Email: & Unspecified & & \\
\hline City: & Unspecified & Fax: & Unspecified & & \\
\hline State: & Unspecified & Zip: & Unspecified & & \\
\hline
\end{tabular}

\section{NEED NOTES AND COMMENTS}

There are no notes for this need. 


$\begin{array}{llll}\text { Community: } & \text { PEMBROKE, TOWN OF } & \text { CID: } & 330119 \\ \text { County: } & \text { MERRIMACK COUNTY } & \text { State: } & \text { New Hampshire }\end{array}$

\begin{tabular}{|c|c|c|c|}
\hline \multicolumn{4}{|c|}{ NEED DETAIL INFORMATION } \\
\hline Need ID: & 100000000010572 & Entered By: & Chuck Wood \\
\hline \multirow[t]{4}{*}{ Source: } & FEMA 5-year letter & Date: & 10/03/1997 \\
\hline & & & FEMA \\
\hline & & & $10 / 3 / 97$ \\
\hline & MAINTENANCE & Need Types: & Add streets to panel \\
\hline & Existing & & \\
\hline
\end{tabular}

\section{PANELS AFFECTED BY THE NEED}

3301190010A (04/02/1979)

\begin{tabular}{|c|c|c|c|c|c|}
\hline Entity: & TOWN OF PEMBROKE & Phone: & 6034854747 & Ext: & Unspecified \\
\hline Last Name: & DOLLARD & First Name: & DONALD W. & & \\
\hline Address 1: & TONW HALL & Title: & ASSESSOR & & \\
\hline Address 2: & 311 PEMBROKE ST. & Email: & Unspecified & & \\
\hline City: & PEMBROKE & Fax: & Unspecified & & \\
\hline State: & $\mathrm{NH}$ & Zip: & $03275-$ & & \\
\hline
\end{tabular}

\section{NEED NOTES AND COMMENTS}

There are no notes for this need. 


\begin{tabular}{|c|c|c|c|}
\hline Community: & SALISBURY, TOWN OF & \multicolumn{2}{|l|}{ CID: } \\
\hline County: & MERRIMACK COUNTY & State: & New Hampshire \\
\hline \multicolumn{4}{|c|}{ NEED DETAIL INFORMATION } \\
\hline Need ID: & 100000000010632 & Entered By: & Chuck Wood \\
\hline \multirow[t]{5}{*}{ Source: } & FEMA 5-year letter & Date: & 11/25/1998 \\
\hline & & & FEMA \\
\hline & & & $11 / 25 / 98$ \\
\hline & MAINTENANCE & Need Types: & Add streets to panel \\
\hline & Existing & & \\
\hline
\end{tabular}

\section{PANELS AFFECTED BY THE NEED}

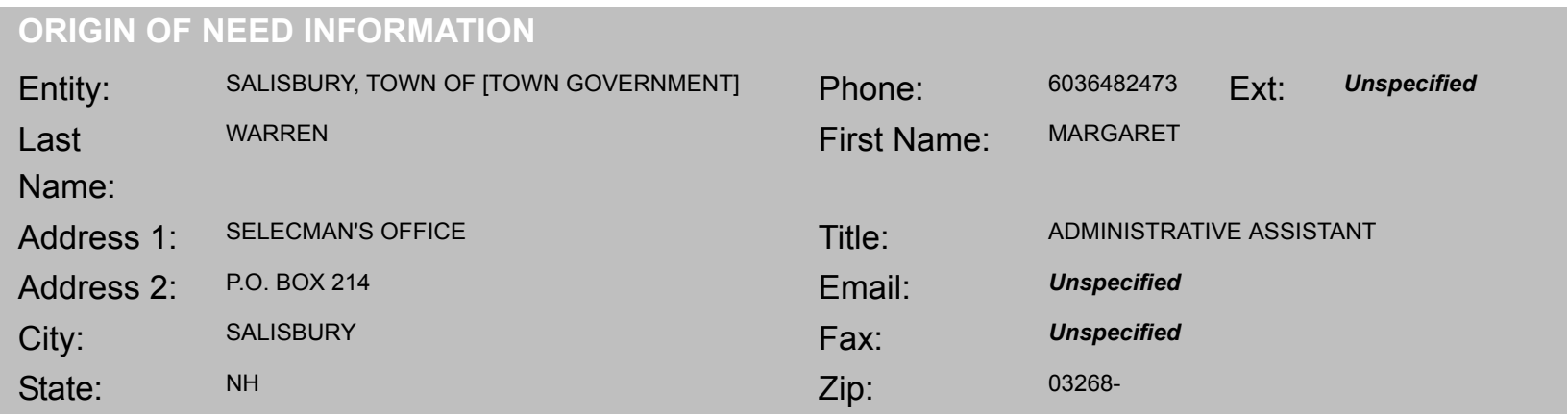

\section{NEED NOTES AND COMMENTS}

There are no notes for this need. 


\section{Appendix C. State and Community Meetings}




\title{
FEMA Map Modernization Program Merrimack County Scoping
}

\section{Scoping Meeting Conference Call Meeting Minutes}

\author{
September 1, 2005
}

U.S. Geological Survey (USGS) held a kick-off meeting via conference call on September 1, 2005, with representatives from New Hampshire Office of Emergency Management (NHOEM), Federal Emergency Management Agency (FEMA), USGS, and Watershed Concepts (RMC - Regional Management Center) to introduce the scoping project team and review roles and responsibilities.

As one of the scoping study process requirements, this conference call was held to review the USGS role in the scoping project process in four counties in New Hampshire (Merrimack, Coos, Belknap, and Carroll Counties) as well as to detail the data requirements of USGS in order to determine restudy needs and prioritization of restudies in these four counties.

\section{Attendance:}

- Dean Savramis, FEMA Map Modernization Coordinator

- Brent McCarthy and Jeff Burm, Watershed Concepts (RMC)

- Fay Rubin, GIS Manager at Complex Systems Research Center, University of New Hampshire

- Robert Flynn, Craig Johnston, and Laura Hayes, USGS

- Joanne Cassulo and Jennifer DeLong, Map Modernization Coordinators, NHOEM

\section{Minutes:}

1. Dean Savramis (FEMA) — Provided an overview of the Map Modernization Program and Scoping. He also provided a description of the countywide approach.

2. Brent McCarthy (Watershed Concepts)—Describe the role of the RMC in assisting FEMA and the mapping contractors. Description of the WISE computer applications developed for FEMA to standardize the scoping process methodology, data collection, and storage for the map modernization program. Description of the DFIRM Production tool.

3. Joanne Cassulo and Jennifer DeLong (NHOEM) — Spoke about CAVs to collect information. NHOEM is providing copies of LOMAs. Joanne mentioned that the regional planning commissions have a lot of data available and can provide community contacts. 
4. Jeff Burm (Watershed Concepts) — mentioned that FEMA's Community Information System (CIS) has CAVs and CACs and access can be gotten from Mike Goetz at FEMA. He also spoke about the WISE scoping tool and various features of this tool including community contact information, available GIS data, stream data, statistical analysis, stream mile information to calculate costs for hydrology and hydraulics, LOMAs, CAVs and CACs, creation of reports for each of the items.

5. Fay Rubin (GRANIT, UNH Complex Systems)—Fay spoke about the Map Modernization work that is being done at FEMA and that she is using DOQs in her map modernization work. Fay mentioned that the Merrimack County digitization is complete, that the Belknap and Carroll County digitization will be complete by December and that the Coos County digitization will be complete next year (due by December of 2006). She stated that NHDOT is in the process of updating DOQs ion southeastern New Hampshire and that they are looking for a vendor to process the data. She mentioned that the 2003 NAIP color DOQs may not meet FEMA specifications. She has the NAIP DOQs in New Hampshire State Plane coordinates (our NAIP DOQs are in UTM projection).

6. Fay Rubin, Craig Johnston, Laura Hayes and Rob Flynn (GRANIT; USGS)—discussed available data and coverages within New Hampshire (for example, 2003 NAIP color DOQs). Remote sensing, base map information, GIS data (for example, contour data, E911 data, DEMs, buildings layer, survey data available from NHDOT). County Regional Planning Commissions may also have data.

7. USGS and NHOEM-Discuss follow-up meetings with communities to discuss prioritization. USGS will need to coordinate with NHOEM and Watershed Concepts to obtain mailing lists for communities and set a date to meet with representatives from each of the towns in each of the counties. Brent McCarthy mentioned that it may be a good idea to set up a morning and evening meeting with each county in order to be able to talk to all of the representatives in each town (two meetings for each county). Brent McCarthy also mentioned that Watershed Concepts could lead breakout sessions with towns during the meetings with the counties. 


\section{Merrimack County Intenview Form \\ FEMA Map Modernization Program}

Date: Effective FIS/FIRM Date:

Community: Form of Government:

CID\#: If Town Government, Date of Annual Town Meeting:

\section{Community Representative:}

Name:

Title:

Telephone \#: Email:

Fax:

\section{Other Appropriate Community Contacts:}

1. Known problems with current FIRMs and FISs for the community (general details on next pages).

a. Base Map Issues (note FIRM panel numbers): (for example, poor/mixed map scales, panels not printed, change in corporate boundaries, etc.)

b. Floodplain Issues (note FIRM panel numbers): (for example, need flood elevations, disagree with floodplain boundaries, flood elevations too high/low, comments from MNUSS or best available data)

2. Areas of approximate study (for example, Zone A's) where detailed re-studies should be considered: 
3. Areas not mapped/no floodplain where approximate or detailed studies should be considered:

4. Changes to structures within the town that may affect river hydraulics (for example, reconstruction or removal of dams, changes to bridges and culverts, etc.):

5. Areas of increased/proposed development within the floodplain since the effective FIS:

1. Availability of mapping at the town level:

a. Aerial Photography (flight date, scale, color/black and white):

b. Topography (contour interval):

c. Other:

2. Future community data acquisition plans/wants/needs:

3. Information on GIS programs in-place or GIS plans that may benefit from a new FIRM:

4. Other comments:

5. Action Items:

Additional Notes: 


\section{Appendix D. Prioritized Flooding Sources}


Appendix D. Prioritized flooding sources in Merrimack County.

[CID, Community Identification; FIS, Flood Insurance Studies; LOMC, Letter of Map Change; --, no data]

\begin{tabular}{|c|c|c|c|c|c|c|c|c|c|c|c|c|c|c|c|c|c|c|}
\hline Community & CID & Reach_ID & Description & $\begin{array}{l}\text { Current } \\
\text { analysis } \\
\text { effective } \\
\text { date }\end{array}$ & $\begin{array}{c}\text { Current } \\
\text { effective } \\
\text { zone }\end{array}$ & $\begin{array}{c}\text { Study } \\
\text { reach } \\
\text { length } \\
\text { (ft) }\end{array}$ & Study type & $\begin{array}{l}\text { Com- } \\
\text { munity } \\
\text { priority } \\
\text { range }\end{array}$ & $\begin{array}{l}\text { Com- } \\
\text { munity } \\
\text { priority }\end{array}$ & $\begin{array}{c}\text { Popu- } \\
\text { lation } \\
\text { density } \\
\text { score }\end{array}$ & $\begin{array}{c}\text { Popu- } \\
\text { lation } \\
\text { growth } \\
\text { score }\end{array}$ & $\begin{array}{c}\text { Year } \\
\text { since } \\
\text { most } \\
\text { recent } \\
\text { FIS } \\
\text { score }\end{array}$ & $\begin{array}{l}\text { Signif- } \\
\text { icant } \\
\text { area } \\
\text { score }\end{array}$ & $\begin{array}{c}\text { De- } \\
\text { velop- } \\
\text { ment } \\
\text { score }\end{array}$ & $\begin{array}{l}\text { LOMC } \\
\text { score }\end{array}$ & $\begin{array}{c}\text { Com- } \\
\text { munity } \\
\text { priority } \\
\text { value }\end{array}$ & $\begin{array}{c}\text { Com- } \\
\text { munity } \\
\text { ranking } \\
\text { value }\end{array}$ & $\begin{array}{l}\text { Total } \\
\text { score }\end{array}$ \\
\hline Hooksett & 330115 & $\begin{array}{l}\text { \{5D716BDA-16D5-41A1- } \\
\text { 84A0-B1239A263C84\} }\end{array}$ & $\begin{array}{l}\text { Heads Pond } \\
(1047777.36,214140.48)\end{array}$ & $3 / 12 / 1982$ & $\mathrm{~A}$ & $7,694.7$ & $\begin{array}{l}\text { Detailed study/ } \\
\text { Riverine }\end{array}$ & $\begin{array}{l}\text { Medium } \\
\text { High }\end{array}$ & 1 & 8 & 6 & 8 & 5 & 5 & 0 & 15 & 10 & 57 \\
\hline Pittsfield & 330120 & $\begin{array}{l}\text { \{6E213E5D-8FF3-4914- } \\
\text { B37D-67E6FE6994C7\} }\end{array}$ & $\begin{array}{l}\text { Whites Pond } \\
(1080578.26,292282.24)\end{array}$ & $7 / 3 / 1978$ & -- & $3,330.3$ & $\begin{array}{l}\text { Detailed study/ } \\
\text { Riverine }\end{array}$ & $\begin{array}{l}\text { Medium } \\
\text { High }\end{array}$ & 1 & 8 & 1 & 10 & 5 & 5 & 0 & 15 & 10 & 54 \\
\hline New London & 330230 & $\begin{array}{l}\{\text { C8BF8B5C-73B4-4EAB- } \\
\text { B4FA-57606DCC508A\} }\end{array}$ & $\begin{array}{l}\text { Whitney Brook } \\
\text { (911728.44, 335456.04) }\end{array}$ & 7/16/1991 & A & $2,688.4$ & $\begin{array}{l}\text { Detailed study/ } \\
\text { Riverine }\end{array}$ & $\begin{array}{l}\text { Medium } \\
\text { High }\end{array}$ & 2 & 8 & 4 & 4 & 5 & 5 & 5 & 15 & 8 & 54 \\
\hline Concord & 330110 & $\begin{array}{l}\text { 89991D004-A6FE-4ACE- } \\
\text { A086-A6A44B4340CA }\end{array}$ & $\begin{array}{l}\text { The Outlet } \\
(998189.22,279146.60)\end{array}$ & 8/23/1999 & -- & $7,451.7$ & $\begin{array}{l}\text { Detailed study/ } \\
\text { Riverine }\end{array}$ & High & 1 & 8 & 2 & 2 & 5 & 5 & 0 & 20 & 10 & 52 \\
\hline Concord & 330110 & $\begin{array}{l}\text { \{6B244ABB-71F7-4FE4- } \\
\text { A3BA-549201877C9C\} }\end{array}$ & $\begin{array}{l}\text { Contoocook River } \\
(996281.43,277703.82)\end{array}$ & 8/23/1999 & $\mathrm{AE}$ & $10,215.1$ & $\begin{array}{l}\text { Limited } \\
\text { detailed study/ } \\
\text { Riverine }\end{array}$ & High & 1 & 8 & 2 & 2 & 5 & 5 & 0 & 20 & 10 & 52 \\
\hline Warner & 330123 & $\begin{array}{l}\text { \{58BB2B22-638A-4451- } \\
\text { A0AE-A7083F1FDAFA }\}\end{array}$ & $\begin{array}{l}\text { Warner River } \\
(934924.54,287337.05)\end{array}$ & $6 / 4 / 1987$ & $\mathrm{AE}$ & $12,850.9$ & $\begin{array}{l}\text { Limited } \\
\text { detailed study }\end{array}$ & High & 1 & 2 & 4 & 6 & 5 & 5 & 0 & 20 & 10 & 52 \\
\hline New London & 330230 & $\begin{array}{l}\text { \{B6FCFAD7-3717-4F8B- } \\
\text { 9B3E-057ED9884DAB }\}\end{array}$ & $\begin{array}{l}\text { Little Sunapee Lake } \\
(894235.75,342124.56)\end{array}$ & 7/16/1991 & A & $10,758.5$ & Detailed study & $\begin{array}{l}\text { Medium } \\
\text { High }\end{array}$ & 1 & 8 & 4 & 4 & 5 & 5 & 0 & 15 & 10 & 51 \\
\hline Concord & 330110 & $\begin{array}{l}\text { \{8DDC9691-E6B6-4203- } \\
\text { AD33-01F9364DFB3D }\}\end{array}$ & $\begin{array}{l}\text { Merrimack River } \\
(1004823.77,286828.77)\end{array}$ & 8/23/1999 & $\mathrm{AE}$ & $18,382.0$ & $\begin{array}{l}\text { Limited } \\
\text { detailed study/ } \\
\text { Riverine }\end{array}$ & $\begin{array}{l}\text { Medium } \\
\text { High }\end{array}$ & 2 & 8 & 2 & 2 & 5 & 5 & 5 & 15 & 8 & 50 \\
\hline Hooksett & 330115 & $\begin{array}{l}\text { \{2BDA4396-BF37-414D- } \\
\text { 9FD0-C10A33F80BAE\} }\end{array}$ & $\begin{array}{l}\text { Dubes Pond } \\
(1052041.26,207899.35)\end{array}$ & $3 / 12 / 1982$ & A & $5,735.8$ & $\begin{array}{l}\text { Detailed study/ } \\
\text { Riverine }\end{array}$ & Medium & 2 & 8 & 6 & 8 & 5 & 5 & 0 & 10 & 8 & 50 \\
\hline Loudon & 330117 & $\begin{array}{l}\{3 \mathrm{C} 2 \mathrm{D} 2 \mathrm{E} 6 \mathrm{E}-3845-4 \mathrm{EBD}- \\
\text { 8F4A-03A311212156\} }\end{array}$ & $\begin{array}{l}\text { Soucook River } \\
(1037392.79,295792.44)\end{array}$ & 9/28/1979 & A & $22,252.3$ & $\begin{array}{l}\text { Detailed study/ } \\
\text { Riverine }\end{array}$ & $\begin{array}{l}\text { Medium } \\
\text { High }\end{array}$ & 1 & 8 & 1 & 1 & 5 & 5 & 5 & 15 & 10 & 50 \\
\hline New London & 330230 & $\begin{array}{l}\text { \{C3AFBE53-192E-4DC7- } \\
\text { AB92-62F3E68DAA78\} }\end{array}$ & $\begin{array}{l}\text { Pleasant Lake } \\
(906852.93,338498.45)\end{array}$ & $7 / 16 / 1991$ & A & $2,120.2$ & Detailed study & $\begin{array}{l}\text { Medium } \\
\text { High }\end{array}$ & 2 & 8 & 4 & 4 & 5 & 5 & 0 & 15 & 8 & 49 \\
\hline New London & 330230 & $\begin{array}{l}\text { \{C3AFBE53-192E-4DC7- } \\
\text { AB92-62F3E68DAA78\} }\end{array}$ & $\begin{array}{l}\text { Pleasant Lake } \\
(905697.35,339078.18)\end{array}$ & 7/16/1991 & A & $1,334.5$ & Detailed study & $\begin{array}{l}\text { Medium } \\
\text { High }\end{array}$ & 2 & 8 & 4 & 4 & 5 & 5 & 0 & 15 & 8 & 49 \\
\hline New London & 330230 & $\begin{array}{l}\text { \{C3AFBE53-192E-4DC7- } \\
\text { AB92-62F3E68DAA78\} }\end{array}$ & $\begin{array}{l}\text { Pleasant Lake } \\
(904813.96,341395.11)\end{array}$ & 7/16/1991 & A & $2,599.0$ & Detailed study & $\begin{array}{l}\text { Medium } \\
\text { High }\end{array}$ & 2 & 8 & 4 & 4 & 5 & 5 & 0 & 15 & 8 & 49 \\
\hline New London & 330230 & $\begin{array}{l}\{\mathrm{C} 8 \mathrm{BF} 8 \mathrm{~B} 5 \mathrm{C}-73 \mathrm{~B} 4-4 \mathrm{EAB}- \\
\text { B4FA-57606DCC } 508 \mathrm{~A}\}\end{array}$ & $\begin{array}{l}\text { Pleasant Lake } \\
(908606.35,337337.79)\end{array}$ & 7/16/1991 & A & $3,718.2$ & Detailed study & $\begin{array}{l}\text { Medium } \\
\text { High }\end{array}$ & 2 & 8 & 4 & 4 & 5 & 5 & 0 & 15 & 8 & 49 \\
\hline Sutton & 330122 & $\begin{array}{l}\{73262940-3904-4129- \\
\text { 87F4-6CC1507A0763\} }\end{array}$ & $\begin{array}{l}\text { Cascade Brook } \\
(918651.45,325967.31)\end{array}$ & $5 / 17 / 1977$ & A & $4,793.5$ & $\begin{array}{l}\text { Detailed study/ } \\
\text { Riverine }\end{array}$ & Medium & 1 & 2 & 1 & 10 & 5 & 5 & 5 & 10 & 10 & 48 \\
\hline Sutton & 330122 & $\begin{array}{l}\{73262940-3904-4129- \\
87 F 4-6 C C 1507 A 0763\}\end{array}$ & $\begin{array}{l}\text { Cascade Brook } \\
(919113.90,326400.84)\end{array}$ & $5 / 17 / 1977$ & A & 931.7 & $\begin{array}{l}\text { Detailed study/ } \\
\text { Riverine }\end{array}$ & Medium & 1 & 2 & 1 & 10 & 5 & 5 & 5 & 10 & 10 & 48 \\
\hline Pittsfield & 330120 & $\begin{array}{l}\{0 F 5 F B 324-F B 18-4649- \\
9 \text { C0F-F56665D5F634\} }\end{array}$ & $\begin{array}{l}\text { Clarks Pond } \\
(1077169.39,292453.44)\end{array}$ & 7/3/1978 & -- & 493.9 & $\begin{array}{l}\text { Detailed study/ } \\
\text { Riverine }\end{array}$ & Medium & 2 & 8 & 1 & 10 & 5 & 5 & 0 & 10 & 8 & 47 \\
\hline Wilmot & 330124 & $\begin{array}{l}\text { \{C8BF8B5C-73B4-4EAB- } \\
\text { B4FA-57606DCC } 508 \mathrm{~A}\}\end{array}$ & $\begin{array}{l}\text { Cascade Brook } \\
(921649.66,334631.99)\end{array}$ & 11/19/1976 & A & $10,832.5$ & $\begin{array}{l}\text { Detailed study/ } \\
\text { Riverine }\end{array}$ & $\begin{array}{l}\text { Medium } \\
\text { High }\end{array}$ & 1 & 2 & 4 & 6 & 5 & 5 & 0 & 15 & 10 & 47 \\
\hline Newbury & 330226 & $\begin{array}{l}\text { \{E40D837F-79A5-47BD- } \\
\text { AE1C-D3946D0EC1A5 }\end{array}$ & $\begin{array}{l}\text { Ring Brook } \\
(900303.96,302358.54)\end{array}$ & 4/2/1986 & A & $3,444.9$ & $\begin{array}{l}\text { Detailed study/ } \\
\text { Riverine }\end{array}$ & $\begin{array}{l}\text { Medium } \\
\text { High }\end{array}$ & 1 & 2 & 4 & 6 & 5 & 5 & 0 & 15 & 10 & 47 \\
\hline Newbury & 330226 & $\begin{array}{l}\text { \{E40D837F-79A5-47BD- } \\
\text { AE1C-D3946D0EC1A5\} }\end{array}$ & $\begin{array}{l}\text { Ring Brook } \\
(900001.38,295721.32)\end{array}$ & $4 / 2 / 1986$ & A & $6,761.6$ & $\begin{array}{l}\text { Detailed study/ } \\
\text { Riverine }\end{array}$ & $\begin{array}{l}\text { Medium } \\
\text { High }\end{array}$ & 1 & 2 & 4 & 6 & 5 & 5 & 0 & 15 & 10 & 47 \\
\hline Newbury & 330226 & $\begin{array}{l}\text { \{E40D837F-79A5-47BD- } \\
\text { AE1C-D3946D0EC1A5 }\end{array}$ & $\begin{array}{l}\text { Ring Brook } \\
(900418.18,299315.19)\end{array}$ & $4 / 2 / 1986$ & A & $4,272.8$ & $\begin{array}{l}\text { Detailed study/ } \\
\text { Riverine }\end{array}$ & $\begin{array}{l}\text { Medium } \\
\text { High }\end{array}$ & 1 & 2 & 4 & 6 & 5 & 5 & 0 & 15 & 10 & 47 \\
\hline New London & 330230 & $\begin{array}{l}\text { \{8A83C96D-3FB4-48A5- } \\
\text { 9AC5-F3E48070229F\} }\end{array}$ & $\begin{array}{l}\text { Messer Pond } \\
(892744.56,330985.95)\end{array}$ & 7/16/1991 & A & $6,406.2$ & Detailed study & $\begin{array}{l}\text { Medium } \\
\text { High }\end{array}$ & 3 & 8 & 4 & 4 & 0 & 5 & 5 & 15 & 6 & 47 \\
\hline Sutton & 330122 & $\begin{array}{l}\{988185 \mathrm{AE}-8435-4 \mathrm{C} 92- \\
\text { 8EB3-3800D744557F }\end{array}$ & $\begin{array}{l}\text { Lane River } \\
(911980.32,298900.52)\end{array}$ & $5 / 17 / 1977$ & A & $22,604.6$ & $\begin{array}{l}\text { Detailed study/ } \\
\text { Riverine }\end{array}$ & $\begin{array}{l}\text { Medium } \\
\text { High }\end{array}$ & 2 & 2 & 1 & 10 & 5 & 0 & 5 & 15 & 8 & 46 \\
\hline
\end{tabular}


Appendix D. Prioritized flooding sources in Merrimack County.-Continued

[CID, Community Identification; FIS, Flood Insurance Studies; LOMC, Letter of Map Change; --, no data]

\begin{tabular}{|c|c|c|c|c|c|c|c|c|c|c|c|c|c|c|c|c|c|c|}
\hline Community & CID & Reach_ID & Description & $\begin{array}{l}\text { Current } \\
\text { analysis } \\
\text { effective } \\
\text { date }\end{array}$ & $\begin{array}{l}\text { Current } \\
\text { effective } \\
\text { zone }\end{array}$ & $\begin{array}{l}\text { Study } \\
\text { reach } \\
\text { length } \\
\text { (ft) }\end{array}$ & Study type & $\begin{array}{c}\text { Com- } \\
\text { munity } \\
\text { priority } \\
\text { range }\end{array}$ & $\begin{array}{l}\text { Com- } \\
\text { munity } \\
\text { priority }\end{array}$ & $\begin{array}{l}\text { Popu- } \\
\text { lation } \\
\text { density } \\
\text { score }\end{array}$ & $\begin{array}{c}\text { Popu- } \\
\text { lation } \\
\text { growth } \\
\text { score }\end{array}$ & $\begin{array}{c}\text { Year } \\
\text { since } \\
\text { most } \\
\text { recent } \\
\text { FIS } \\
\text { score }\end{array}$ & $\begin{array}{l}\text { Signif- } \\
\text { icant } \\
\text { area } \\
\text { score }\end{array}$ & $\begin{array}{c}\text { De- } \\
\text { velop- } \\
\text { ment } \\
\text { score }\end{array}$ & $\begin{array}{l}\text { LOMC } \\
\text { score }\end{array}$ & $\begin{array}{c}\text { Com- } \\
\text { munity } \\
\text { priority } \\
\text { value }\end{array}$ & $\begin{array}{l}\text { Com- } \\
\text { munity } \\
\text { ranking } \\
\text { value }\end{array}$ & $\begin{array}{l}\text { Total } \\
\text { score }\end{array}$ \\
\hline Andover & 330104 & $\begin{array}{l}\text { \{FEFA0970-D853-4F85- } \\
\text { B618-E951A2D83861\} }\end{array}$ & $\begin{array}{l}\text { Blackwater River } \\
(930608.33,339351.61)\end{array}$ & $4 / 2 / 1986$ & A & $24,953.4$ & $\begin{array}{l}\text { Detailed study/ } \\
\text { Riverine }\end{array}$ & $\begin{array}{l}\text { Medium } \\
\text { High }\end{array}$ & 1 & 2 & 2 & 6 & 5 & 5 & 0 & 15 & 10 & 45 \\
\hline Andover & 330104 & $\begin{array}{l}\text { \{FEFA0970-D853-4F85- } \\
\text { B618-E951A2D83861\} }\end{array}$ & $\begin{array}{l}\text { Blackwater River } \\
(950220.54,339823.08)\end{array}$ & $4 / 2 / 1986$ & A & $14,411.7$ & $\begin{array}{l}\text { Detailed study/ } \\
\text { Riverine }\end{array}$ & $\begin{array}{l}\text { Medium } \\
\text { High }\end{array}$ & 1 & 2 & 2 & 6 & 5 & 5 & 0 & 15 & 10 & 45 \\
\hline Bow & 330107 & $\begin{array}{l}\{158 \text { AC221-D0B1-4DA0- } \\
\text { 8675-BB88EFA47D5A }\}\end{array}$ & $\begin{array}{l}\text { Bow Bog Brook } \\
(1030374.10,230410.68)\end{array}$ & $11 / 20 / 2000$ & A & $17,834.4$ & $\begin{array}{l}\text { Detailed study/ } \\
\text { Riverine }\end{array}$ & $\begin{array}{l}\text { Medium } \\
\text { High }\end{array}$ & 1 & 8 & 6 & 1 & 5 & 0 & 0 & 15 & 10 & 45 \\
\hline Andover & 330104 & $\begin{array}{l}\text { \{F6E7B5EA-907F-4097- } \\
\text { 88D8-04624251AD4F }\}\end{array}$ & $\begin{array}{l}\text { Sucker Brook } \\
(962298.64,348324.40)\end{array}$ & 4/2/1986 & A & $24,594.0$ & $\begin{array}{l}\text { Detailed study/ } \\
\text { Riverine }\end{array}$ & $\begin{array}{l}\text { Medium } \\
\text { High }\end{array}$ & 2 & 2 & 2 & 6 & 5 & 5 & 0 & 15 & 8 & 43 \\
\hline Andover & 330104 & $\begin{array}{l}\text { \{F6E7B5EA-907F-4097- } \\
\text { 88D8-04624251AD4F\} }\end{array}$ & $\begin{array}{l}\text { Sucker Brook } \\
(964567.04,342014.42)\end{array}$ & $4 / 2 / 1986$ & A & $5,866.2$ & $\begin{array}{l}\text { Detailed study/ } \\
\text { Riverine }\end{array}$ & $\begin{array}{l}\text { Medium } \\
\text { High }\end{array}$ & 2 & 2 & 2 & 6 & 5 & 5 & 0 & 15 & 8 & 43 \\
\hline Andover & 330104 & $\begin{array}{l}\text { \{FEFA0970-D853-4F85- } \\
\text { B618-E951A2D83861\} }\end{array}$ & $\begin{array}{l}\text { Blackwater River } \\
(930164.48,340693.27)\end{array}$ & 4/2/1986 & A & $1,443.2$ & $\begin{array}{l}\text { Detailed study/ } \\
\text { Riverine }\end{array}$ & $\begin{array}{l}\text { Medium } \\
\text { High }\end{array}$ & 2 & 2 & 2 & 6 & 5 & 5 & 0 & 15 & 8 & 43 \\
\hline Webster & 330236 & $\begin{array}{l}\text { \{C2F195FD-02F6-4C8C- } \\
\text { A5D5-8A346EB5B4A7 }\end{array}$ & $\begin{array}{l}\text { Lake Winnepocket } \\
(965834.67,294363.50)\end{array}$ & 6/2/1993 & -- & $4,546.1$ & Detailed study & $\begin{array}{l}\text { Medium } \\
\text { High }\end{array}$ & 1 & 2 & 2 & 4 & 5 & 5 & 0 & 15 & 10 & 43 \\
\hline Webster & 330236 & $\begin{array}{l}\{25 \mathrm{E} 6 \mathrm{E} 49 \mathrm{E}-\mathrm{E} 135-451 \mathrm{C}- \\
\text { 9D38-E4C7F4106F5E }\}\end{array}$ & $\begin{array}{l}\text { Pillsbury Lake } \\
(980353.82,283709.07)\end{array}$ & $6 / 2 / 1993$ & -- & $5,512.6$ & Detailed study & $\begin{array}{l}\text { Medium } \\
\text { High }\end{array}$ & 2 & 2 & 2 & 4 & 5 & 5 & 0 & 15 & 8 & 41 \\
\hline Pittsfield & 330120 & $\begin{array}{l}\{156 \mathrm{CA} 3 \mathrm{~B} 8-6 \mathrm{AE} 1-4216- \\
\text { AEF5-510EF4D2C117\} }\end{array}$ & $\begin{array}{l}\text { Berry Pond Brook } \\
(1076662.40,292280.23)\end{array}$ & 7/3/1978 & -- & $5,098.9$ & $\begin{array}{l}\text { Detailed study/ } \\
\text { Riverine }\end{array}$ & $\begin{array}{l}\text { Medium } \\
\text { High }\end{array}$ & 3 & 8 & 1 & 10 & 0 & 0 & 0 & 15 & 6 & 40 \\
\hline Warner & 330123 & $\begin{array}{l}\{6 \text { AE0B980-FEBE-4852- } \\
\text { B754-20382389510F }\}\end{array}$ & $\begin{array}{l}\text { Slaughter Brook } \\
(927755.12,276870.31)\end{array}$ & $6 / 4 / 1987$ & -- & $10,384.7$ & $\begin{array}{l}\text { Detailed study/ } \\
\text { Riverine }\end{array}$ & $\begin{array}{l}\text { Medium } \\
\text { High }\end{array}$ & 2 & 2 & 4 & 6 & 5 & 0 & 0 & 15 & 8 & 40 \\
\hline Wilmot & 330124 & $\begin{array}{l}\text { \{C8BF8B5C-73B4-4EAB- } \\
\text { B4FA-57606DCC508A\} }\end{array}$ & $\begin{array}{l}\text { Cassey Brook } \\
(920358.82,337359.44)\end{array}$ & $11 / 19 / 1976$ & A & $3,638.6$ & $\begin{array}{l}\text { Detailed study/ } \\
\text { Riverine }\end{array}$ & $\begin{array}{l}\text { Medium } \\
\text { High }\end{array}$ & 2 & 2 & 4 & 6 & 5 & 0 & 0 & 15 & 8 & 40 \\
\hline Newbury & 330226 & $\begin{array}{l}\{8 \text { 8B7B6BD5-EB4E-4082- } \\
\text { A264-D0FF0CC991F3\} }\end{array}$ & $\begin{array}{l}\text { Andrew Brook } \\
(897352.57,290261.65)\end{array}$ & 4/2/1986 & A & $3,411.4$ & $\begin{array}{l}\text { Detailed study/ } \\
\text { Riverine }\end{array}$ & Medium & 2 & 2 & 4 & 6 & 5 & 5 & 0 & 10 & 8 & 40 \\
\hline Bow & 330107 & $\begin{array}{l}\text { \{C9DFB5EE-41F6-47A2- } \\
\text { 93B8-DBE41D2106CF\} }\end{array}$ & $\begin{array}{l}\text { Bow Bog Brook } \\
\text { Tributary } \\
(1030014.01,232365.77)\end{array}$ & $11 / 20 / 2000$ & A & $4,074.9$ & Detailed study & Medium & 2 & 8 & 6 & 1 & 5 & 0 & 0 & 10 & 8 & 38 \\
\hline Hooksett & 330115 & $\begin{array}{l}\{\text { BEDE6865-839A-45C0- } \\
\text { B38E-0F2C7C68F480\} }\end{array}$ & $\begin{array}{l}\text { Dalton Brook } \\
(1048509.26,201092.52)\end{array}$ & $3 / 12 / 1982$ & $\mathrm{X}$ & $2,526.3$ & $\begin{array}{l}\text { Detailed study/ } \\
\text { Riverine }\end{array}$ & Medium & 3 & 8 & 6 & 8 & 0 & 0 & 0 & 10 & 6 & 38 \\
\hline Hooksett & 330115 & $\begin{array}{l}\text { \{BEDE6865-839A-45C0- } \\
\text { B38E-0F2C7C68F480\} }\end{array}$ & $\begin{array}{l}\text { Dalton Brook } \\
(1046328.59,200630.97)\end{array}$ & $3 / 12 / 1982$ & $\mathrm{AE}$ & $1,709.8$ & $\begin{array}{l}\text { Limited } \\
\text { detailed study/ } \\
\text { Riverine }\end{array}$ & Medium & 3 & 8 & 6 & 8 & 0 & 0 & 0 & 10 & 6 & 38 \\
\hline Warner & 330123 & $\begin{array}{l}\{0 \mathrm{~A} 0 \mathrm{E} 1 \mathrm{E} 70-1637-4 \mathrm{E} 78- \\
\text { 990F-E8ABC134833B }\end{array}$ & $\begin{array}{l}\text { Stevens Brook } \\
(935371.08,296917.65)\end{array}$ & $6 / 4 / 1987$ & -- & $12,414.1$ & $\begin{array}{l}\text { Detailed study/ } \\
\text { Riverine }\end{array}$ & $\begin{array}{l}\text { Medium } \\
\text { High }\end{array}$ & 3 & 2 & 4 & 6 & 0 & 5 & 0 & 15 & 6 & 38 \\
\hline Wilmot & 330124 & $\begin{array}{l}\{73262940-3904-4129- \\
87 F 4-6 C C 1507 A 0763\}\end{array}$ & $\begin{array}{l}\text { Cascade Brook } \\
(921838.07,332642.17)\end{array}$ & 11/19/1976 & A & $4,210.5$ & $\begin{array}{l}\text { Detailed study/ } \\
\text { Riverine }\end{array}$ & $\begin{array}{l}\text { Medium } \\
\text { High }\end{array}$ & 3 & 2 & 4 & 6 & 0 & 5 & 0 & 15 & 6 & 38 \\
\hline Wilmot & 330124 & $\begin{array}{l}\{73262940-3904-4129- \\
87 \mathrm{~F} 4-6 \mathrm{CC} 1507 \mathrm{~A} 0763\}\end{array}$ & $\begin{array}{l}\text { Cascade Brook } \\
(922205.87,333891.08)\end{array}$ & $11 / 19 / 1976$ & A & $1,564.3$ & $\begin{array}{l}\text { Detailed study/ } \\
\text { Riverine }\end{array}$ & $\begin{array}{l}\text { Medium } \\
\text { High }\end{array}$ & 3 & 2 & 4 & 6 & 0 & 5 & 0 & 15 & 6 & 38 \\
\hline Wilmot & 330124 & $\begin{array}{l}\{73262940-3904-4129- \\
87 \mathrm{~F} 4-6 \mathrm{CC} 1507 \mathrm{~A} 0763\}\end{array}$ & $\begin{array}{l}\text { Cascade Brook } \\
(922831.30,334442.62)\end{array}$ & $11 / 19 / 1976$ & A & 878.9 & $\begin{array}{l}\text { Detailed study/ } \\
\text { Riverine }\end{array}$ & $\begin{array}{l}\text { Medium } \\
\text { High }\end{array}$ & 3 & 2 & 4 & 6 & 0 & 5 & 0 & 15 & 6 & 38 \\
\hline Wilmot & 330124 & $\begin{array}{l}\{73262940-3904-4129- \\
87 F 4-6 C C 1507 A 0763\}\end{array}$ & $\begin{array}{l}\text { Cascade Brook } \\
(922792.64,334718.01)\end{array}$ & 11/19/1976 & A & 140.7 & $\begin{array}{l}\text { Detailed study/ } \\
\text { Riverine }\end{array}$ & $\begin{array}{l}\text { Medium } \\
\text { High }\end{array}$ & 3 & 2 & 4 & 6 & 0 & 5 & 0 & 15 & 6 & 38 \\
\hline Concord & 330110 & $\begin{array}{l}\text { \{63622084-C9E8-4653- } \\
\text { 91C4-73D94CA201EA }\end{array}$ & $\begin{array}{l}\text { Hayward Brook } \\
(1016303.72,292746.23)\end{array}$ & 8/23/1999 & A & $8,857.9$ & $\begin{array}{l}\text { Detailed study/ } \\
\text { Riverine }\end{array}$ & $\begin{array}{l}\text { Medium } \\
\text { High }\end{array}$ & 4 & 8 & 2 & 2 & 0 & 5 & 0 & 15 & 4 & 36 \\
\hline Concord & 330110 & $\begin{array}{l}\{\text { E5F75244-1971-4A19- } \\
\text { B0A6-4B257A10852B }\end{array}$ & $\begin{array}{l}\text { Bela Brook } \\
(1003259.87,238475.89)\end{array}$ & 8/23/1999 & A & $9,204.7$ & $\begin{array}{l}\text { Detailed study/ } \\
\text { Riverine }\end{array}$ & Medium & 7 & 8 & 2 & 2 & 0 & 5 & 5 & 10 & 4 & 36 \\
\hline Wilmot & 330124 & $\begin{array}{l}\text { \{C8BF8B5C-73B4-4EAB- } \\
\text { B4FA-57606DCC508A\} }\end{array}$ & $\begin{array}{l}\text { Whitney Brook } \\
(913817.00,335241.95)\end{array}$ & $11 / 19 / 1976$ & A & 753.6 & $\begin{array}{l}\text { Detailed study/ } \\
\text { Riverine }\end{array}$ & Medium & 6 & 2 & 4 & 6 & 0 & 5 & 5 & 10 & 4 & 36 \\
\hline
\end{tabular}


Appendix D. Prioritized flooding sources in Merrimack County.-Continued

[CID, Community Identification; FIS, Flood Insurance Studies; LOMC, Letter of Map Change; --, no data]

\begin{tabular}{|c|c|c|c|c|c|c|c|c|c|c|c|c|c|c|c|c|c|c|}
\hline Community & CID & Reach_ID & Description & $\begin{array}{l}\text { Current } \\
\text { analysis } \\
\text { effective } \\
\text { date }\end{array}$ & $\begin{array}{c}\text { Current } \\
\text { effective } \\
\text { zone }\end{array}$ & $\begin{array}{c}\text { Study } \\
\text { reach } \\
\text { length } \\
\text { (ft) }\end{array}$ & Study type & $\begin{array}{c}\text { Com- } \\
\text { munity } \\
\text { priority } \\
\text { range }\end{array}$ & $\begin{array}{l}\text { Com- } \\
\text { munity } \\
\text { priority }\end{array}$ & $\begin{array}{l}\text { Popu- } \\
\text { lation } \\
\text { density } \\
\text { score }\end{array}$ & $\begin{array}{l}\text { Popu- } \\
\text { lation } \\
\text { growth } \\
\text { score }\end{array}$ & $\begin{array}{c}\text { Year } \\
\text { since } \\
\text { most } \\
\text { recent } \\
\text { FIS } \\
\text { score }\end{array}$ & $\begin{array}{l}\text { Signif- } \\
\text { icant } \\
\text { area } \\
\text { score }\end{array}$ & $\begin{array}{c}\text { De- } \\
\text { velop- } \\
\text { ment } \\
\text { score }\end{array}$ & $\begin{array}{l}\text { LOMC } \\
\text { score }\end{array}$ & $\begin{array}{c}\text { Com- } \\
\text { munity } \\
\text { priority } \\
\text { value }\end{array}$ & $\begin{array}{c}\text { Com- } \\
\text { munity } \\
\text { ranking } \\
\text { value }\end{array}$ & $\begin{array}{l}\text { Total } \\
\text { score }\end{array}$ \\
\hline Wilmot & 330124 & $\begin{array}{l}\text { \{C8BF8B5C-73B4-4EAB- } \\
\text { B4FA-57606DCC508A }\end{array}$ & $\begin{array}{l}\text { Whitney Brook } \\
(914508.50,335263.95)\end{array}$ & 11/19/1976 & A & $3,833.8$ & $\begin{array}{l}\text { Detailed study/ } \\
\text { Riverine }\end{array}$ & Medium & 6 & 2 & 4 & 6 & 0 & 5 & 5 & 10 & 4 & 36 \\
\hline Concord & 330110 & $\begin{array}{l}\text { \{77A413FE-0D41-4F1E- } \\
\text { 9A35-30EFD5ACF503\} }\end{array}$ & $\begin{array}{l}\text { Millers Brook } \\
(1007284.13,257396.80)\end{array}$ & 8/23/1999 & -- & 162.6 & $\begin{array}{l}\text { Detailed study/ } \\
\text { Riverine }\end{array}$ & Medium & 2 & 8 & 2 & 2 & 5 & 0 & 0 & 10 & 8 & 35 \\
\hline New London & 330230 & $\begin{array}{l}\{18554505-9655-4 F 79- \\
\text { A25F-640F329384F4 }\}\end{array}$ & $\begin{array}{l}\text { Sunapee Lake } \\
(887453.75,331692.37)\end{array}$ & 7/16/1991 & $\mathrm{AE}$ & $11,436.3$ & Redelineation & Medium & 4 & 8 & 4 & 4 & 0 & 5 & 0 & 10 & 4 & 35 \\
\hline New London & 330230 & $\begin{array}{l}\{\text { F4D35C0E-0447-4324- } \\
8298-14562 \text { F4C2AA6 }\end{array}$ & $\begin{array}{l}\text { Sunapee Lake } \\
(885011.38,324296.44)\end{array}$ & 7/16/1991 & $\mathrm{AE}$ & $2,326.6$ & Redelineation & Medium & 4 & 8 & 4 & 4 & 0 & 5 & 0 & 10 & 4 & 35 \\
\hline New London & 330230 & $\begin{array}{l}\text { \{225194A9-9D2B-4879- } \\
\text { 98DC-D5FF167A3FE3\} }\end{array}$ & $\begin{array}{l}\text { Sunapee Lake } \\
(884308.69,322844.15)\end{array}$ & 7/16/1991 & $\mathrm{AE}$ & $1,964.3$ & Redelineation & Medium & 4 & 8 & 4 & 4 & 0 & 5 & 0 & 10 & 4 & 35 \\
\hline New London & 330230 & $\begin{array}{l}\{18554505-9655-4 \mathrm{~F} 79- \\
\text { A25F-640F329384F4 }\}\end{array}$ & $\begin{array}{l}\text { Sunapee Lake } \\
(882338.25,333797.55)\end{array}$ & 7/16/1991 & $\mathrm{AE}$ & $1,602.9$ & Redelineation & Medium & 4 & 8 & 4 & 4 & 0 & 5 & 0 & 10 & 4 & 35 \\
\hline New London & 330230 & $\begin{array}{l}\{\mathrm{B} 20 \mathrm{D} 7 \mathrm{D} 36-7 \mathrm{E} 3 \mathrm{~B}-4 \mathrm{C} 28- \\
\text { BA08-1704164BF801\} }\end{array}$ & $\begin{array}{l}\text { Sunapee Lake } \\
(880321.74,336504.88)\end{array}$ & 7/16/1991 & $\mathrm{AE}$ & 785.5 & Redelineation & Medium & 4 & 8 & 4 & 4 & 0 & 5 & 0 & 10 & 4 & 35 \\
\hline New London & 330230 & $\begin{array}{l}\text { \{034F2C79-E139-498A- } \\
\text { A260-F090A31FDF85 }\end{array}$ & $\begin{array}{l}\text { Sunapee Lake } \\
(881280.11,335191.46)\end{array}$ & 7/16/1991 & $\mathrm{AE}$ & $1,495.9$ & Redelineation & Medium & 4 & 8 & 4 & 4 & 0 & 5 & 0 & 10 & 4 & 35 \\
\hline Andover & 330104 & $\begin{array}{l}\text { \{D35DCD4C-FB39-43D0- } \\
\text { 95F6-73DEAD6EBA13\} }\end{array}$ & $\begin{array}{l}\text { Unnamed Brook } \\
(959616.56,345402.02)\end{array}$ & $4 / 2 / 1986$ & A & 328.5 & Detailed study & Medium & 2 & 2 & 2 & 6 & 5 & 0 & 0 & 10 & 8 & 33 \\
\hline Andover & 330104 & $\begin{array}{l}\text { \{D35DCD4C-FB39-43D0- } \\
\text { 95F6-73DEAD6EBA13\} }\end{array}$ & $\begin{array}{l}\text { Unnamed Brook } \\
(958661.52,346206.31)\end{array}$ & $4 / 2 / 1986$ & A & $1,252.0$ & $\begin{array}{l}\text { Detailed study/ } \\
\text { Riverine }\end{array}$ & Medium & 2 & 2 & 2 & 6 & 5 & 0 & 0 & 10 & 8 & 33 \\
\hline Concord & 330110 & $\begin{array}{l}\{726787 \mathrm{D} 1-\mathrm{C} 679-454 \mathrm{C}- \\
\text { A7F2-07CF38E3EE24\} }\end{array}$ & $\begin{array}{l}\text { Beaver Meadow Brook } \\
(1006132.42,274740.88)\end{array}$ & 8/23/1999 & -- & $12,911.9$ & Detailed study & Medium & 3 & 8 & 2 & 2 & 0 & 5 & 0 & 10 & 6 & 33 \\
\hline Concord & 330110 & $\begin{array}{l}\{\text { D5E36619-3BE3-4564- } \\
\text { B744-911BDA49344D }\}\end{array}$ & $\begin{array}{l}\text { Mill Brook } \\
(1022097.62,269687.96)\end{array}$ & 8/23/1999 & A & $8,150.9$ & Detailed study & Medium & 3 & 8 & 2 & 2 & 0 & 5 & 0 & 10 & 6 & 33 \\
\hline Concord & 330110 & $\begin{array}{l}\text { \{BC58336D-D8D6-4800- } \\
\text { B794-8F8142C92373\} }\end{array}$ & $\begin{array}{l}\text { Turee Brook } \\
(1010759.24,241247.76)\end{array}$ & 8/23/1999 & A & $6,083.6$ & Detailed study & Medium & 10 & 8 & 2 & 2 & 0 & 5 & 0 & 10 & 4 & 31 \\
\hline Concord & 330110 & $\begin{array}{l}\text { \{7E8EDC3E-05F8-42B6- } \\
\text { 892F-6CD8F441B47B }\end{array}$ & $\begin{array}{l}\text { White Brook } \\
(1008954.71,240312.38)\end{array}$ & 8/23/1999 & A & $2,104.3$ & Detailed study & Medium & 10 & 8 & 2 & 2 & 0 & 5 & 0 & 10 & 4 & 31 \\
\hline Concord & 330110 & $\begin{array}{l}\{4 \mathrm{~A} 287 \mathrm{C} 3 \mathrm{E}-5 \mathrm{E} 47-40 \mathrm{~F} 2- \\
\text { A19C-854E0C208511\} }\end{array}$ & $\begin{array}{l}\text { Little Turkey Pond } \\
\text { (1006937.34, 244471.99) }\end{array}$ & 8/23/1999 & A & 880.8 & Detailed study & Medium & 8 & 8 & 2 & 2 & 0 & 5 & 0 & 10 & 4 & 31 \\
\hline Concord & 330110 & $\begin{array}{l}\{4 \mathrm{~A} 287 \mathrm{C} 3 \mathrm{E}-5 \mathrm{E} 47-40 \mathrm{~F} 2- \\
\text { A19C-854E0C } 208511\}\end{array}$ & $\begin{array}{l}\text { Little Turkey Pond } \\
(1005922.31,243671.13)\end{array}$ & 8/23/1999 & A & $6,412.5$ & Detailed study & Medium & 8 & 8 & 2 & 2 & 0 & 5 & 0 & 10 & 4 & 31 \\
\hline Concord & 330110 & $\begin{array}{l}\{\mathrm{CC} 16505 \mathrm{~B}-7 \mathrm{D} 93-49 \mathrm{E} 1- \\
\text { BB43-F049695AD0E0\} }\end{array}$ & $\begin{array}{l}\text { Turkey River } \\
(1003041.31,252112.32)\end{array}$ & $8 / 23 / 1999$ & A & $8,643.8$ & $\begin{array}{l}\text { Detailed study/ } \\
\text { Riverine }\end{array}$ & Medium & 10 & 8 & 2 & 2 & 0 & 5 & 0 & 10 & 4 & 31 \\
\hline Concord & 330110 & $\begin{array}{l}\{4 \mathrm{~A} 287 \mathrm{C} 3 \mathrm{E}-5 \mathrm{E} 47-40 \mathrm{~F} 2- \\
\text { A19C-854E0C } 208511\}\end{array}$ & $\begin{array}{l}\text { Little Turkey Pond } \\
(1003600.63,248790.68)\end{array}$ & 8/23/1999 & A & $3,826.1$ & Detailed study & Medium & 9 & 8 & 2 & 2 & 0 & 5 & 0 & 10 & 4 & 31 \\
\hline Concord & 330110 & $\begin{array}{l}\{4 \mathrm{~A} 287 \mathrm{C} 3 \mathrm{E}-5 \mathrm{E} 47-40 \mathrm{~F} 2- \\
\text { A19C-854E0C208511\} }\end{array}$ & $\begin{array}{l}\text { Little Turkey Pond } \\
(1001448.19,252033.43)\end{array}$ & 8/23/1999 & A & $1,854.2$ & Detailed study & Medium & 9 & 8 & 2 & 2 & 0 & 5 & 0 & 10 & 4 & 31 \\
\hline Concord & 330110 & $\begin{array}{l}\{\mathrm{CC} 16505 \mathrm{~B}-7 \mathrm{D} 93-49 \mathrm{E} 1- \\
\text { BB43-F049695AD0E0\} }\end{array}$ & $\begin{array}{l}\text { Turkey River } \\
(1013069.43,248216.64)\end{array}$ & 8/23/1999 & A & $10,403.0$ & $\begin{array}{l}\text { Detailed study/ } \\
\text { Riverine }\end{array}$ & Medium & 10 & 8 & 2 & 2 & 0 & 5 & 0 & 10 & 4 & 31 \\
\hline Concord & 330110 & $\begin{array}{l}\{\mathrm{CC} 16505 \mathrm{~B}-7 \mathrm{D} 93-49 \mathrm{E} 1- \\
\text { BB43-F049695AD0E0\} }\end{array}$ & $\begin{array}{l}\text { Turkey River } \\
(1011858.76,249625.21)\end{array}$ & 8/23/1999 & A & $2,726.0$ & $\begin{array}{l}\text { Detailed study/ } \\
\text { Riverine }\end{array}$ & Medium & 10 & 8 & 2 & 2 & 0 & 5 & 0 & 10 & 4 & 31 \\
\hline Concord & 330110 & $\begin{array}{l}\text { \{CC16505B-7D93-49E1- } \\
\text { BB43-F049695AD0E0\} }\end{array}$ & $\begin{array}{l}\text { Turkey River } \\
(1008927.48,252163.30)\end{array}$ & 8/23/1999 & A & $6,975.4$ & $\begin{array}{l}\text { Detailed study/ } \\
\text { Riverine }\end{array}$ & Medium & 10 & 8 & 2 & 2 & 0 & 5 & 0 & 10 & 4 & 31 \\
\hline Wilmot & 330124 & $\begin{array}{l}\{\text { DBE90B08-67A1-4A24- } \\
\text { B341-8C030B5F152E }\end{array}$ & $\begin{array}{l}\text { Kimpton Brook } \\
(924219.20,345121.30)\end{array}$ & $11 / 19 / 1976$ & A & $13,283.2$ & $\begin{array}{l}\text { Detailed study/ } \\
\text { Riverine }\end{array}$ & Medium & 7 & 2 & 4 & 6 & 0 & 0 & 5 & 10 & 4 & 31 \\
\hline Wilmot & 330124 & $\begin{array}{l}\{\text { DBE90B08-67A1-4A24- } \\
\text { B341-8C030B5F152E }\end{array}$ & $\begin{array}{l}\text { Kimpton Brook } \\
(913532.70,349611.74)\end{array}$ & $11 / 19 / 1976$ & A & 438.0 & $\begin{array}{l}\text { Detailed study/ } \\
\text { Riverine }\end{array}$ & Medium & 7 & 2 & 4 & 6 & 0 & 0 & 5 & 10 & 4 & 31 \\
\hline
\end{tabular}


Appendix D. Prioritized flooding sources in Merrimack County.-Continued

[CID, Community Identification; FIS, Flood Insurance Studies; LOMC, Letter of Map Change; --, no data]

\begin{tabular}{|c|c|c|c|c|c|c|c|c|c|c|c|c|c|c|c|c|c|c|}
\hline Community & CID & Reach_ID & Description & $\begin{array}{c}\text { Current } \\
\text { analysis } \\
\text { effective } \\
\text { date }\end{array}$ & $\begin{array}{l}\text { Current } \\
\text { effective } \\
\text { zone }\end{array}$ & $\begin{array}{l}\text { Study } \\
\text { reach } \\
\text { length } \\
\text { (ft) }\end{array}$ & Study type & $\begin{array}{c}\text { Com- } \\
\text { munity } \\
\text { priority } \\
\text { range }\end{array}$ & $\begin{array}{l}\text { Com- } \\
\text { munity } \\
\text { priority }\end{array}$ & $\begin{array}{l}\text { Popu- } \\
\text { lation } \\
\text { density } \\
\text { score }\end{array}$ & $\begin{array}{l}\text { Popu- } \\
\text { lation } \\
\text { growth } \\
\text { score }\end{array}$ & $\begin{array}{c}\text { Year } \\
\text { since } \\
\text { most } \\
\text { recent } \\
\text { FIS } \\
\text { score }\end{array}$ & $\begin{array}{l}\text { Signif- } \\
\text { icant } \\
\text { area } \\
\text { score }\end{array}$ & $\begin{array}{c}\text { De- } \\
\text { velop- } \\
\text { ment } \\
\text { score }\end{array}$ & $\begin{array}{l}\text { LOMC } \\
\text { score }\end{array}$ & $\begin{array}{l}\text { Com- } \\
\text { munity } \\
\text { priority } \\
\text { value }\end{array}$ & $\begin{array}{l}\text { Com- } \\
\text { munity } \\
\text { ranking } \\
\text { value }\end{array}$ & $\begin{array}{l}\text { Total } \\
\text { score }\end{array}$ \\
\hline Wilmot & 330124 & $\begin{array}{l}\text { \{C8BF8B5C-73B4-4EAB- } \\
\text { B4FA-57606DCC508A }\end{array}$ & $\begin{array}{l}\text { Tannery Pond } \\
(919537.59,334276.39)\end{array}$ & $11 / 19 / 1976$ & A & $2,458.1$ & Detailed study & Medium & 4 & 2 & 4 & 6 & 0 & 5 & 0 & 10 & 4 & 31 \\
\hline Wilmot & 330124 & $\begin{array}{l}\text { \{C8BF8B5C-73B4-4EAB- } \\
\text { B4FA-57606DCC508A\} }\end{array}$ & $\begin{array}{l}\text { Chase Pond } \\
(917226.62,333705.68)\end{array}$ & 11/19/1976 & A & $2,774.7$ & Detailed study & Medium & 5 & 2 & 4 & 6 & 0 & 5 & 0 & 10 & 4 & 31 \\
\hline Andover & 330104 & $\begin{array}{l}\text { \{C8BF8B5C-73B4-4EAB- } \\
\text { B4FA-57606DCC508A\} }\end{array}$ & $\begin{array}{l}\text { Cascade Brook } \\
(927420.51,337697.60)\end{array}$ & 4/2/1986 & A & $4,803.7$ & $\begin{array}{l}\text { Detailed study/ } \\
\text { Riverine }\end{array}$ & Medium & 3 & 2 & 2 & 6 & 0 & 0 & 0 & 10 & 6 & 28 \\
\hline Concord & 330110 & $\begin{array}{l}\{06 \mathrm{C} 906 \mathrm{AF}-755 \mathrm{E}-4 \mathrm{E} 96- \\
\text { AC53-1D86666A16AC }\end{array}$ & $\begin{array}{l}\text { Ash Brook } \\
(1001171.00,252372.56)\end{array}$ & 8/23/1999 & A & 457.4 & $\begin{array}{l}\text { Detailed study/ } \\
\text { Riverine }\end{array}$ & Medium & 9 & 8 & 2 & 2 & 0 & 0 & 0 & 10 & 4 & 26 \\
\hline Concord & 330110 & $\begin{array}{l}\text { \{77860711-B07B-4F9A- } \\
\text { 8DA1-37B55956A092\} }\end{array}$ & $\begin{array}{l}\text { Hackett Brook } \\
(1021414.90,288314.69)\end{array}$ & $8 / 23 / 1999$ & A & $7,277.5$ & $\begin{array}{l}\text { Detailed study/ } \\
\text { Riverine }\end{array}$ & Medium & 4 & 8 & 2 & 2 & 0 & 0 & 0 & 10 & 4 & 26 \\
\hline Concord & 330110 & $\begin{array}{l}\{06 \mathrm{C} 906 \mathrm{AF}-755 \mathrm{E}-4 \mathrm{E} 96- \\
\text { AC53-1D86666A16AC }\}\end{array}$ & $\begin{array}{l}\text { Ash Brook } \\
(996313.90,256124.60)\end{array}$ & 8/23/1999 & A & $8,417.5$ & $\begin{array}{l}\text { Detailed study/ } \\
\text { Riverine }\end{array}$ & Medium & 9 & 8 & 2 & 2 & 0 & 0 & 0 & 10 & 4 & 26 \\
\hline Concord & 330110 & $\begin{array}{l}\text { \{77A413FE-0D41-4F1E- } \\
\text { 9A35-30EFD5ACF503\} }\end{array}$ & $\begin{array}{l}\text { Millers Brook } \\
(1008625.14,254994.54)\end{array}$ & 8/23/1999 & -- & $4,174.2$ & Detailed study & Medium & 5 & 8 & 2 & 2 & 0 & 0 & 0 & 10 & 4 & 26 \\
\hline Concord & 330110 & $\begin{array}{l}\{77 \mathrm{~A} 413 \mathrm{FE}-0 \mathrm{D} 41-4 \mathrm{~F} 1 \mathrm{E}- \\
\text { 9A35-30EFD5ACF503\} }\end{array}$ & $\begin{array}{l}\text { Millers Brook } \\
(1007384.32,257268.73)\end{array}$ & $8 / 23 / 1999$ & -- & $2,942.8$ & $\begin{array}{l}\text { Detailed study/ } \\
\text { Riverine }\end{array}$ & Medium & 5 & 8 & 2 & 2 & 0 & 0 & 0 & 10 & 4 & 26 \\
\hline Concord & 330110 & $\begin{array}{l}\text { \{0818A6D8-5ED7-4FEA- } \\
\text { A7C5-6499D313C6AD }\end{array}$ & $\begin{array}{l}\text { Millers Brook } \\
(1007629.02,259744.54)\end{array}$ & $8 / 23 / 1999$ & -- & $3,502.2$ & $\begin{array}{l}\text { Detailed study/ } \\
\text { Riverine }\end{array}$ & Medium & 5 & 8 & 2 & 2 & 0 & 0 & 0 & 10 & 4 & 26 \\
\hline Concord & 330110 & $\begin{array}{l}\{5 \text { F800174-80E7-42BB- } \\
\text { BE60-E21EFB8F3760\} }\end{array}$ & $\begin{array}{l}\text { Hoit Road Marsh Outlet } \\
(1021390.62,288883.17)\end{array}$ & $8 / 23 / 1999$ & -- & 461.9 & Detailed study & Medium & 4 & 8 & 2 & 2 & 0 & 0 & 0 & 10 & 4 & 26 \\
\hline Warner & 330123 & $\begin{array}{l}\text { \{C79DD47A-530D-41A3- } \\
\text { 8F97-4E7621E7BB0B }\end{array}$ & $\begin{array}{l}\text { French Brook } \\
(937045.88,298912.22)\end{array}$ & 6/4/1987 & -- & $4,544.0$ & $\begin{array}{l}\text { Detailed study/ } \\
\text { Riverine }\end{array}$ & Medium & 4 & 2 & 4 & 6 & 0 & 0 & 0 & 10 & 4 & 26 \\
\hline Andover & 330104 & $\begin{array}{l}\text { \{FB1811E6-F546-430D- } \\
\text { 8B12-C2A59B946B0D }\end{array}$ & $\begin{array}{l}\text { Punch Brook } \\
(964783.23,339003.25)\end{array}$ & 4/2/1986 & A & 400.5 & Detailed study & Medium & 6 & 2 & 2 & 6 & 0 & 0 & 0 & 10 & 4 & 24 \\
\hline Andover & 330104 & $\begin{array}{l}\{711 \mathrm{BC} 930-8 \mathrm{E} 8 \mathrm{E}-48 \mathrm{~A}- \\
\text { A612-92279891421E }\end{array}$ & $\begin{array}{l}\text { Unnamed Stream } \\
(955544.91,339047.38)\end{array}$ & 4/2/1986 & A & $2,725.7$ & Detailed study & Medium & 5 & 2 & 2 & 6 & 0 & 0 & 0 & 10 & 4 & 24 \\
\hline Andover & 330104 & $\begin{array}{l}\{862 \mathrm{D} 18 \mathrm{CA}-\mathrm{CD} 18-4 \mathrm{~F} 30- \\
\text { 8807-9D487D560F92\} }\end{array}$ & $\begin{array}{l}\text { Unnamed Stream } \\
(954402.44,341235.01)\end{array}$ & 4/2/1986 & A & $2,802.5$ & Detailed study & Medium & 4 & 2 & 2 & 6 & 0 & 0 & 0 & 10 & 4 & 24 \\
\hline Wilmot & 330124 & $\begin{array}{l}\text { \{BBC72434-6C88-4775- } \\
\text { B41B-9577F14C9504\} }\end{array}$ & $\begin{array}{l}\text { Eagle Pond } \\
(925436.13,351138.87)\end{array}$ & $11 / 19 / 1976$ & A & $3,957.9$ & Detailed study & $\begin{array}{l}\text { Medium } \\
\text { Low }\end{array}$ & 8 & 2 & 4 & 6 & 0 & 0 & 0 & 5 & 4 & 21 \\
\hline
\end{tabular}




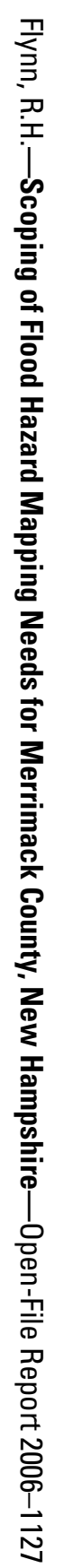

Printed on recycled paper 